Article

\title{
The Influence of Canopy Cover on the Ecological Function of A Key Autogenic Ecosystem Engineer
}

\author{
Jacqueline B. Pocklington ${ }^{1,2, *}$, Michael J. Keough ${ }^{2}$, Tim D. O'Hara ${ }^{1}$ and Alecia Bellgrove ${ }^{3}$ \\ 1 Department of Marine Invertebrates, Museum Victoria, Carlton, VIC 3053, Australia; \\ tohara@museum.vic.gov.au \\ 2 School of BioSciences, University of Melbourne, Parkville, VIC 3010, Australia; mjkeough@unimelb.edu.au \\ 3 School of Life and Environmental Sciences, Centre for Integrative Ecology, Deakin University, \\ Warrnambool Campus, PO Box 423, Warrnambool, VIC 3280, Australia; alecia.bellgrove@deakin.edu.au \\ * Correspondence: jpocklin@gmail.com
}

Received: 8 April 2019; Accepted: 15 May 2019; Published: 17 May 2019

check for updates

\begin{abstract}
Intertidal fucoid algae can function as ecosystem engineers across temperate marine regions. In this investigation, we assessed the function of the alga dominating rocky reefs in temperate Australia and New Zealand, Hormosira banksii. Invertebrate and algal species assemblages were examined within areas of full H. banksii canopy, areas where it was naturally patchy or absent (within its potential range on the shore) and areas where the intact canopy was experimentally disturbed. Differences in species assemblages were detected between areas with natural variation in $H$. banksii cover (full, patchy, negligible), with defined species associated with areas of full cover. Differences were also detected between experimentally manipulated and naturally patchy areas of canopy cover. Species assemblages altered in response to canopy manipulations and did not recover even twelve months after initial sampling. Both light intensity and temperature were buffered by full canopies compared to patchy canopies and exposed rock. This study allows us to predict the consequences to the intertidal community due to the loss of canopy cover, which may result from a range of disturbances such as trampling, storm damage, sand burial and prolonged exposure to extreme temperature, and further allow for improved management of this key autogenic ecosystem engineer.
\end{abstract}

Keywords: macroalgae; facilitation; disturbance; invertebrates; intertidal reef

\section{Introduction}

Canopy-forming seaweeds can function as autogenic ecosystem engineers on rocky seashores, providing a suitable habitat for species that would otherwise be excluded or only occur in low abundance [1-15]. Many studies referring to species as autogenic ecosystem engineers [16,17] (or similar theoretical terms such as dominant species [18], facilitators, habitat-forming species [9] and biogenic habitat) have investigated the associated loss of species when this one species is lost through a major disturbance. What hasn't been examined in full is whether the fucoid intertidal alga Hormosira banksii functions as an ecosystem engineer under varying densities in the absence of disturbance. Is it dependent on spatial dominance, or can it function as part of a mosaic of habitat density and type? Here we demonstrate through both mensurative and manipulative experiments how $H$. banksii functions as an autogenic ecosystem engineer, and how its ability to modify conditions, and thus habitat provision, differs under varying canopy cover. We also show that manipulative experiments alone cannot demonstrate that $H$. banksii is an autogenic ecosystem engineer (defined as changing the environment via its physical structure, [3]) and habitat provider on Victorian rocky shores.

Throughout its range, the fucoid Hormosira banksii is the dominant canopy-forming species on intertidal rocky shores, and unlike studies of fucoids in the northern hemisphere, it has no functional 
equivalent or ecological successor $[2,5,6,9,12,19-29]$, likely due in part to its specialised ability to cope with harsh environmental conditions associated with Austral summers during tidal emersion [30]. Few studies examining the response of $H$. banksii understorey communities to disturbance have investigated the response of more than a few species or components (e.g., functional groups) of the system $[9,12,17,25,31]$. These studies highlight the potential for $H$. banksii to be categorised as an autogenic ecosystem engineer, though none have yet examined whether $H$. banksii also shows this function under naturally reduced densities.

Disturbance studies have shown that damage to $H$. banksii through trampling or experimental removal causes a decline in the abundance of species usually associated with the canopy $[2,5,6,9,12]$. $H$. banksii canopy-removal experiments in New Zealand $[9,27]$ found that temperature was lower within the canopy in comparison to areas where it was removed and this was most apparent during the summer months when surface temperatures in removal plots were at least $5{ }^{\circ} \mathrm{C}$ higher than in control plots [9]. Lilley and Schiel [9] found that understorey algae declined in abundance, and an influx of ephemeral algae occurred (e.g., Ulva spp., Colpomenia sinuosa). The abundance of invertebrates also changed where some species declined in abundance (e.g., Micrelenchus tesselatus, as Cantharidella tesselata) and some increased (e.g., Notoacmea spp.). Trampling experiments in south-eastern Australia have shown that bare rock habitat and its associated fauna weren't detrimentally impacted by trampling, yet $H$. banksii was damaged even at low trampling intensities with a lack of recovery even after 400 days in heavy trampling treatments [2]. Invertebrates common to bare areas were found to colonise the heavily damaged areas of $H$. banksii indicating the possibility of a shift in the community from trampling [2]. In contrast, King [21] found that variable responses to trampling and suggested that seasonal changes potentially obscure the impacts of trampling disturbance. Although both of these trampling studies found low power was a problem in testing the responses of individual species to trampling disturbance [2,21], they did, however, show that different species assemblages occupy different parts of the shore and that high variability is indicative of complexity beyond simple facilitative relationships.

The ecological function of $H$. banksii may vary in space and time and given the results of disturbance studies $[2,5,6,9,12]$, the magnitude of its habitat provision could depend on its physical structure or canopy 'cover'. Previous studies, however, have not examined the species relationships that occur with naturally reduced 'patchy' canopies. Here we examine whether the ability of $H$. banksii to modulate the understorey environment (e.g., light, temperature, desiccation stress) for associated species [3] varies in relation to canopy cover which is naturally variable on Victorian rocky shores. This study investigated the relationship between $H$. banksii and co-occurring species using mensurative surveys examining natural patterns and experimental manipulations at multiple sites, to determine whether the amount of canopy cover influences the autogenic ecosystem engineering function of $H$. banksii on Victorian rocky shores.

\section{Materials and Methods}

\subsection{Study Sites}

All sites were moderately wave-exposed sites facing Bass Strait [32]. On Victorian shores (south-eastern Australia), areas within the vertical range of $H$. banksii can be separated into: full beds (continuous canopy cover with little to no understorey visible), patchy areas (canopy cover is interspersed with 'bare' rock (devoid of observable biota), sand or alternate biota such as mussels or turfing algae), and areas where it is rare or absent (see Figure A1 for examples). All the study reefs were flat calcarenite reef platforms with a mixture of habitat types including extensive Hormosira banksii beds and sections of platform without canopy, comprising turf-forming algae, mussels and 'bare' rock (hereafter referred to as 'negligible').

Although substratum temperatures often exceed $30^{\circ} \mathrm{C}$ during low tide in the summer months, the study species Hormosira banksii has a high tolerance to desiccation due to its unique fluid-filled beaded 
morphology and the presence of UV filters (physodes) in the cell walls [30]; thus H. banksii is the only fucoid capable of forming a canopy in the intertidal of mainland temperate Australia. The Victorian coastline has a micro-tidal range (below $2 \mathrm{~m},[33]$ ); all sites were sampled when tides were predicted to be below $0.4 \mathrm{~m}$ above mean low water (MLW).

Four sites were surveyed including two sites selected for manipulative experiments on canopy cover hereafter referred to as "experiment" sites and two sites selected to compare to the controls at experiment sites hereafter referred to as "background" sites. Experiment Sites: Bridgewater Bay, Mornington Peninsula, Victoria, Australia and 13th Beach 32W (Barwon Heads), Bellarine Peninsula, Victoria, Australia are both backed by steep headlands (Figure 1). Bridgewater Bay is a narrower platform $(30 \mathrm{~m})$ than 13th Beach $(60 \mathrm{~m})$ though both extend for hundreds of metres along the shoreline. Background Survey Sites: Sorrento Back Beach, Mornington Peninsula, Victoria, Australia (see control area in Reference [29]) and Point Roadknight, Anglesea, Victoria, Australia are both very large platforms hundreds of meters long, and approximately 100-m wide (Figure 1). Sorrento Back Beach runs parallel along the coastline, whereas Point Roadknight forms a southerly point.

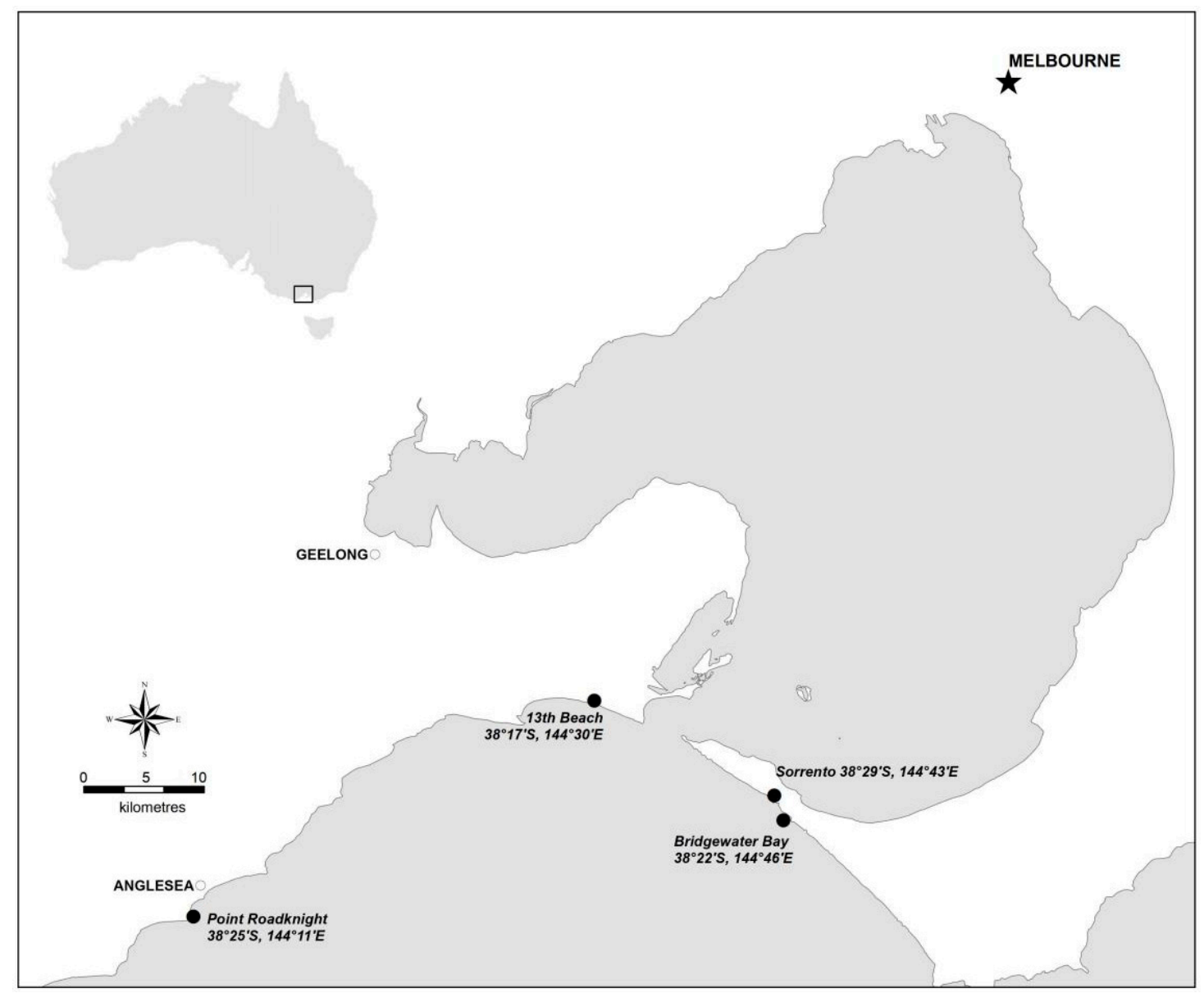

Figure 1. Map showing study sites (black filled circles) including latitudes and longitudes. Bridgewater Bay and 13th Beach are experiment sites, Sorrento and Point Roadknight are background sites. All sites on the coast of the Southern Ocean, Bass Strait is directly south (not shown).

\subsection{Investigation of Species Associations with Natural Variations in Canopy Cover of Hormosira banksii}

To determine the species assemblages associated with the $H$. banksii canopy, sampling was undertaken at the two background sites and two experimental sites prior to experimental manipulation (see experimental investigation) using haphazardly placed quadrats $\left(0.09 \mathrm{~m}^{2}\right)$ within the area of H. banksii distribution on the platform. Sampling occurred within three distinguished habitat types: negligible $(<5 \%)$, patchy $(\sim 40 \%-80 \%$ configured as multiple large clumps separated by 'bare' rock 
without H. banksii), and full (>90\%) areas of H. banksii canopy (see Figure A1). These discrete habitats were highly variable in their connectivity to one another. In each habitat, replicate quadrats $\left(0.09 \mathrm{~m}^{2}\right)$ were quantitatively sampled for percentage cover (using 49-point intercepts) of all components (e.g., sand, rock), sessile aggregating species (e.g., Capreolia implexa, Xenostrobus pulex both $\leq 1 \mathrm{~cm}$ ). The abundance of all mobile and sedentary macroinvertebrate species was individually counted both on fronds of Hormosira and on the substrate beneath the canopy (background sites $\mathrm{n}=10$, experiment sites $n=5$; see full species list Table A1). Percentage cover records included quantifying the primary cover layer which includes all dominant components and biota (referred to throughout as 'primary') and the layer below the canopy (referred to throughout as 'understorey'). In negligible and removed plots where there is no canopy the 'understorey' is equivalent to the primary cover and where described as understorey, it is presented to serve comparison. Organisms were identified to the lowest taxonomic level possible. The depth of sand over rock was measured within quadrats at three random points to the nearest $2.5 \mathrm{~mm}$. The lengths of the longest $\mathrm{H}$. banksii fronds were recorded within quadrats from 3 randomly selected fronds to the nearest $2.5 \mathrm{~mm}$. Sampling was undertaken during two visits per site to account for temporal variability in species abundances (Point Roadknight: January and December 2007 (summer); Sorrento: May and December 2007 (autumn and summer respectively)).

\subsection{Experimental Investigation of the Effect of Variations in Canopy Cover of Hormosira banksii on the Physical Environment and Associated Species Assemblages}

To examine whether algal and macroinvertebrate communities are influenced by the presence of full, patchy or absent canopies; an experiment was carried out at two intertidal rock platforms (13th Beach and Bridgewater Bay). Twenty-five fixed $0.25 \mathrm{~m}^{2}$ plots were established haphazardly across a reef area approximately $10,000 \mathrm{~m}^{2}$ within three categories of canopy cover and marked with labelled cattle tags fixed with stainless steel screws. Five plots were in areas where $H$. banskii was naturally absent $(0 \%-5 \%), 5$ in areas where $H$. banksii had naturally a patchy cover $(40 \%-80 \%)$ and 15 were established in areas with full canopies ( $>95 \%$, full control plots). Ten of these full plots (five replicates each) were randomly assigned to the experimental manipulations: thinned $(40 \%-80 \%)$ and removed $(0 \%-5 \%)$; the five remaining plots remained as full controls. Hormosira banksii cover was reduced by trimming the algal fronds in the experimental plots just above the holdfast using garden secateurs (to prevent long term disturbance by allowing regrowth from holdfasts, Underwood [24]). Any fronds that could overlay the plots from the outside edge were also trimmed. Furthermore, any regrowth above $5 \mathrm{~mm}$ was retrimmed as necessary creating a press disturbance (recovery was not a question of interest). Sampling of plots was undertaken as for the background sites using $0.09 \mathrm{~m}^{2}$ gridded quadrats placed in the centre of each plot. Taxa were identified to species in situ where possible (see Table A1 for full species list). Depth of sand to rock was measured within quadrats at three random points to the nearest $2.5 \mathrm{~mm}$. The longest frond of each of three randomly chosen $H$. banksii plants was measured in each quadrat. To examine whether $H$. banksii modifies the physical environment to the understorey; temperature was recorded on the substratum of each plot using a waterproof thermometer to one decimal place, and relative light intensity on the substratum was recorded using a custom-built meter (JR Pocklington) including a light sensitive diode connected to a standard electrical meter, which measured the degree of shading. Temperature and light readings were taken beneath the canopy within plots (as they were being sampled for species assemblage). All measurements and surveys for all plots were conducted during on low tide, at each sampling time. Sampling intervals roughly followed a logarithmic time series; at 13th Beach: 1, 5, 15, and 379 days after manipulation (23/2/2007, 27/2/2007, 9/3/2007, 13/3/2008; time $\mathrm{n}=4)$; at Bridgewater Bay: 1, 15, 19, and 371 days after manipulation (23/3/2007, 27/3/2007, 10/4/2007, 28/3/2008; time $n=4)$. The experiment start dates and sampling intervals differed slightly between sites on two occasions due to logistical difficulties. Long intervals across the winter period were due to low tide predictions being too high to expose the $H$. banksii zone, or only occurring during the night when species assemblages may differ from day records and accurate sampling couldn't be guaranteed. 


\subsection{Data Analysis}

Comparisons of species assemblages associated with both different natural levels of Hormosira cover and experimental manipulations of Hormosira canopy cover were assessed with multivariate analyses using PRIMER 6 version 6.1.1 and PERMANOVA + version 1.0.5 (PRIMER-E Ltd, 2013, Plymouth, UK). Differences in primary cover, understorey cover and mobile invertebrate assemblages between Hormosira-cover treatments were visualised separately for natural and manipulated covers using Non-metric Multidimensional Scaling (NMDS) [34] based on Bray-Curtis dissimilarities. Ordinations were accepted if stress values were $<0.20$ and ideally $<0.10$ (as recommended by Reference [35]). Shepherds Plots were examined to confirm the goodness of fit. Two-factor permutational multivariate analyses of variance (PERMANOVAs) were performed on fourth-root transformed data with 999 permutations for both natural (baseline) and manipulated covers, examining primary cover, understorey cover and mobile invertebrate assemblages separately. For comparisons of assemblages associated with different natural levels of Hormosira cover prior to manipulation, treatments (three levels: full, patchy, negligible; fixed) and sites (four levels: 13th Beach, Bridgewater Bay, Point Roadknight, Sorrento; random) were compared by PERMANOVA, but because logistical constraints prevented starting experiments and sampling all sites at the same times, any temporal differences in assemblages is incorporated into the unexplained residual variation in analyses. To examine the influence of experimental manipulation of Hormosira canopy cover on associated assemblages, treatments (five levels: full, patchy, negligible, thinned, removed; fixed) and sites (two levels: 13th Beach, Bridgewater Bay; random) were compared by PERMANOVA at each of days 1, 5, 15/19, and 371/379 since experimental manipulation. Tests for homogeneity of dispersions within treatment groups were performed using PERMDISP [36] with distance to centroids. When the treatment $\times$ site interaction was significant another PERMANOVA was run on the interaction term comparing treatments individually by site. In these cases, the $P$-value based on Monte Carlo random draws, $P(M C)$ was selected as it is more robust with the reduced number of possible permutations in pairwise tests [36]. Similarity Percentages (SIMPER) was used to assess the contributions ( $>10 \%$ ) of individual taxa/cover-groups to the separation of treatments. Repeated measures analyses of variance (rmANOVA) were then used to determine the differences in abundances of individual taxa/cover-groups identified by SIMPER amongst treatments and between sites over time (at days 1, 5, 15/19, and 371/379 since experimental manipulation). The physical factors of temperature and light intensity; and the covariates sand depth and Hormosira frond length were also analysed using rmANOVA amongst treatments and between sites over time. All univariate analyses were conducted using SYSTAT version 10 and $\alpha=0.05$ for all statistical analyses. Assumptions of rmANOVA were assessed by examination of probability and residual plots; the abundance of individual mobile invertebrates was square root transformed, otherwise no data transformations were necessary.

\section{Results}

\subsection{Investigation of Species Associations with Natural Variations in Canopy Cover of Hormosira banksii}

The differences in assemblages associated with natural variation in canopy cover of Hormosira were not consistent amongst sites for the primary cover, understorey cover or mobile invertebrates (PERMANOVA treatment $\times$ site interactions; $\mathrm{P}($ perm $)=0.001$ for all analyses). However, for all sites, there were significant differences in the primary cover assemblages between full, patchy and negligible natural Hormosira-cover categories as expected (PERMANOVA on category $\times$ site interaction terms; $\mathrm{P}($ perm $)<0.05$ for all pairwise comparisons for each site; Figure 2a). The understorey and mobile invertebrate assemblages associated with these natural cover categories (full, patchy and negligible Hormosira) showed some spatial variability (and potentially temporal variability due to differences in sampling times of sites), but both understorey and mobile invertebrate assemblages differed significantly amongst all natural cover categories for each site (PERMANOVA on category $x$ site interaction terms; $\mathrm{P}($ perm $)<0.05$ for all pairwise comparisons for each site), except full vs. patchy at 13 th Beach $(\mathrm{P}($ perm $)=0.138$ and 0.227 for understorey cover and mobile invertebrate assemblages, 
respectively; Figure $2 b, c$ ) and patchy vs. negligible cover for mobile invertebrate assemblages at both Bridgewater Bay and Point Roadknight (P(perm) $=0.165$ and 0.075, respectively; Figure 2c). The differences in all assemblages (primary cover, understorey cover and mobile invertebrates) between natural Hormosira-cover categories were, at least in part, due to differences in dispersion amongst Hormosira-cover categories (PERMDISP by categories: $\mathrm{P}(\mathrm{perm})=0.001$ for all analyses; Figure 2 ).
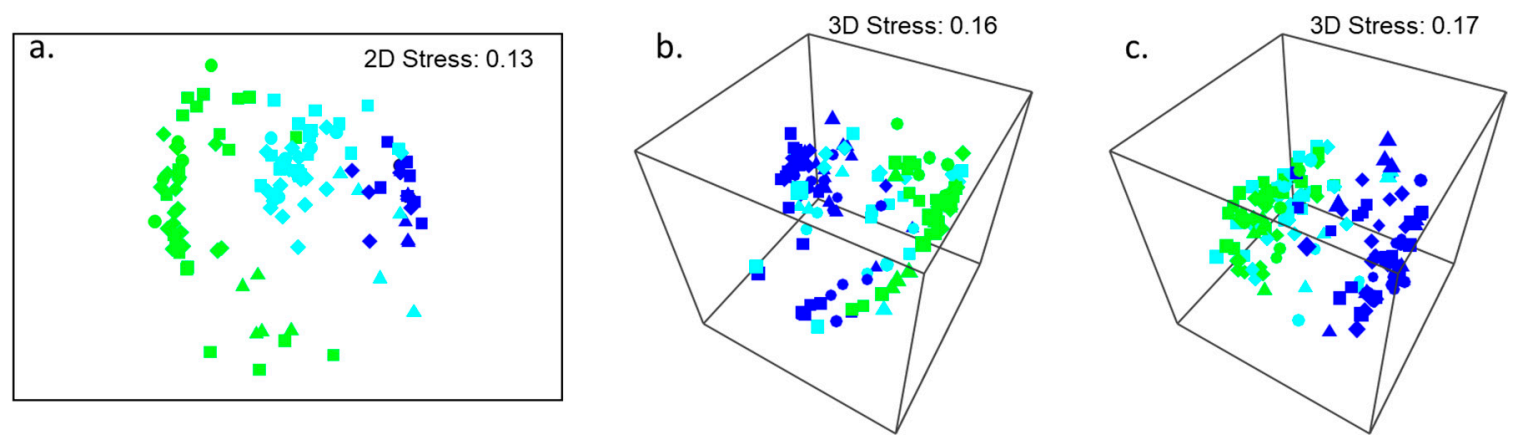

Figure 2. Non-metric multidimensional scaling (nMDS) plots of (a) primary cover, (b) understorey cover and (c) mobile invertebrates assemblages associated with different natural levels of Hormosira cover prior to manipulation (full cover $=$ dark blue, patchy cover $=$ aqua, negligible cover $=$ green) at each of four sites (13th Beach $=$ triangles, Bridgewater Bay $=$ circles, Point Roadknight $=$ squares, Sorrento $=$ diamonds). All data were fourth-root transformed. 3D nMDS plots are shown where stress exceeded 0.20 for $2 \mathrm{D}$ plots.

As expected, the differences in the primary cover assemblages amongst Hormosira-cover categories identified by SIMPER were primarily driven by differences in the percentage cover of Hormosira, with substrata devoid of visible biota (hereafter 'bare rock') and the presence of the mussel Xenostrobus pulex, further contributing to separation of patchy and negligible Hormosira-cover categories, respectively. For the understorey cover, the presence of sand in both full and patchy Hormosira-cover categories contributed $35 \%$ and $59 \%$, respectively, to the separation amongst categories (mean \pm SE\% cover of sand across all sites: $65 \% \pm 5.2$ and $24 \% \pm 6.1$, respectively), whereas the presence of bare rock, X. pulex, the serpulid worm Galeolaria caespitosa and the rhodophyte Capreolia implexa contributed to $88 \%$ of the separation of the negligible Hormosira-cover categories (mean $\pm \mathrm{SE} \%$ cover across all sites: $41 \% \pm 4.9,31 \% \pm 5.2,3 \% \pm 1.0,12 \% \pm 3.5$, respectively). Mobile invertebrate assemblages were defined by the presence of the gastropods Chlorodiloma adelaidae, Lunella undulata, Cominella lineolata and Dicathais orbita contributing $88 \%$ of the separation of the full cover category; the herbivorous gastropods Bembicium nanum, Austrocochlea constricta and a few pulmonates and prosobranch limpet species contributing $86 \%$ of the separation of the patchy cover category; and the presence of $B$. nanum and several pulmonate and prosobranch limpet species contributed to $91 \%$ of the separation of the negligible Hormosira-cover category (Figure 3). 

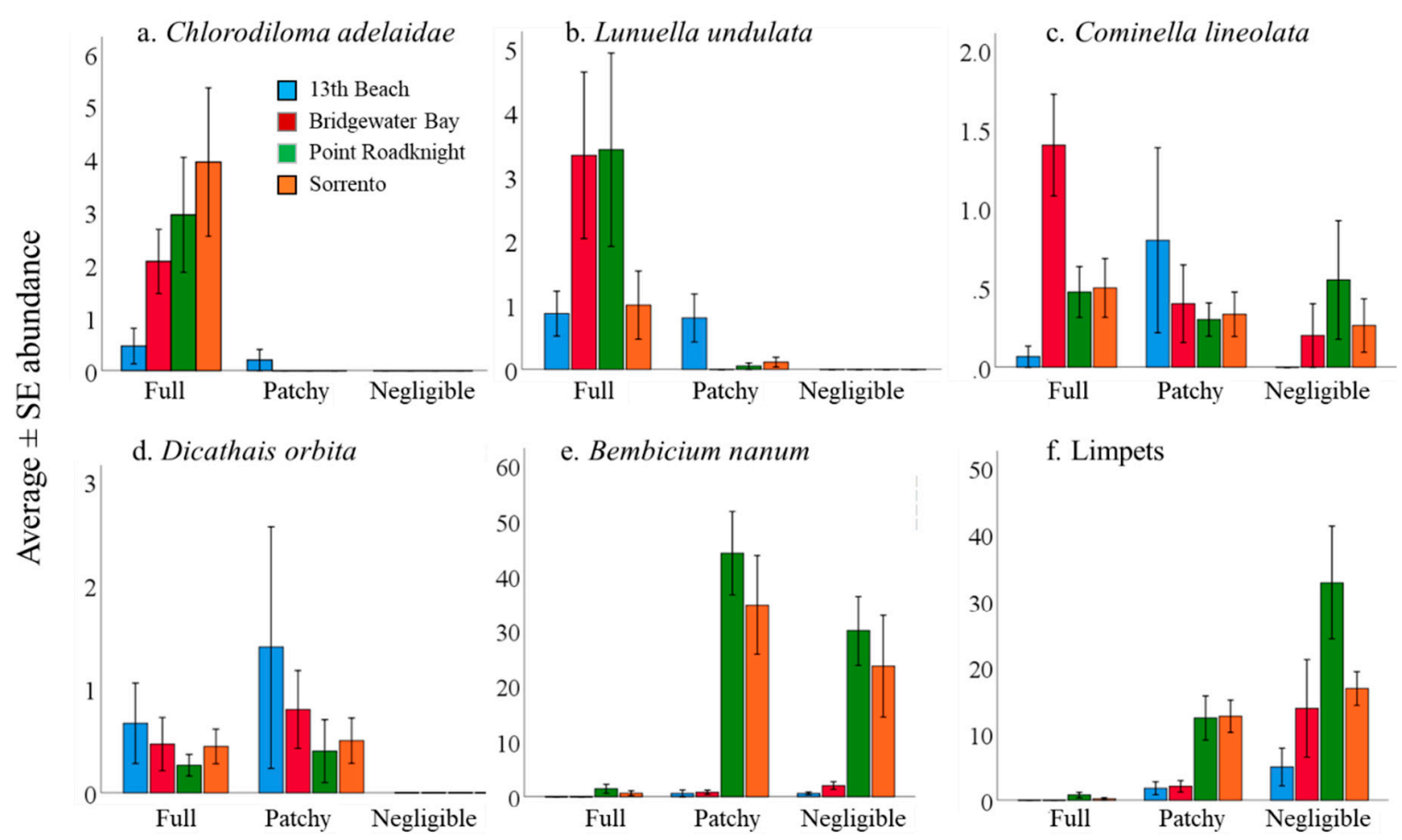

Natural Hormosira-cover treatment

Figure 3. (a) Average $\pm \mathrm{SE}$ densities of mobile invertebrates (per $0.09 \mathrm{~m}^{2}$ quadrat) amongst natural Hormosira cover treatments for each of four sites: (a) Chlorodiloma adelaidae, (b) Lunella undulata, (c) Cominella lineolata, (d) Dicathais orbita, (e) Bembicium nanum, (f) Limpets (Siphonaria spp., Cellana tramoserica, Patelloida spp. combined). $\mathrm{N}=5$ for all treatments at 13 th Beach and Bridgewater Bay and $\mathrm{N}=10$ for Point Roadknight and Sorrento.

3.2. Experimental Investigation of the Effect of Variations in Canopy Cover of Hormosira banksii on the Physical Environment and Associated Species Assemblages

Canopy cover of Hormosira banksii remained within the parameters of the experimental treatments and controls over the course of the experiment (Table 1, Figure 4). However, after experimental manipulation of the Hormosira canopy cover, the differences in both understorey cover and mobile invertebrates assemblages associated with canopy-cover treatments were not consistent amongst sites for any time point (PERMANOVA treatment $\times$ site interactions; $P($ perm $)<0.05$ for all analyses). In several cases differences between treatments were, at least in part, due to differences in dispersion amongst treatment groups at various time points for both understorey cover (PERMDISP by treatments $P($ perm $)<$ 0.005 for days $5,15 / 19$ and $371 / 379$ post manipulation) and mobile invertebrate assemblages (PERMDISP by treatments $P($ perm $)<0.03$ for days 5 and 371/379 post manipulation; Figure A2, Figure A3). 
Table 1. Summary repeated measures analysis of variance (rmANOVA) results comparing factors of interest and abundances of individual taxa and understorey cover components contributing significantly (identified by Similarity Percentage (SIMPER) to differences amongst Hormosira-canopy treatments, sites and time. Only times when sampling of the two sites were close to each other were included for analysis: days 1, 5, 15/19 and 371/379. MS Residual $($ as MS $\mathrm{R}$ ) and degrees of freedom (df) are provided to allow reconstruction of the full ANOVA table. * denotes $P$-values that were adjusted to Greenhouse-Geisser Epsilon, + denotes data Square-Root transformed to meet assumptions of normality, n.s = not significant $(p>0.05)$.

\begin{tabular}{|c|c|c|c|c|c|c|c|}
\hline Factor & $\begin{array}{c}\text { Time } \times \text { Site } \times \text { Treatment } \\
d \mathbf{d f}=\mathbf{1 2}\end{array}$ & $\begin{array}{c}\text { Time } \times \text { Treatment } \\
d f=12\end{array}$ & $\begin{array}{c}\text { Time } \times \text { Site } \\
\mathrm{df}=12\end{array}$ & $\begin{array}{c}\text { Time } \\
\mathrm{df}=3\end{array}$ & $\begin{array}{c}\text { Site } \times \text { Treatment } \\
\text { df }=4\end{array}$ & $\begin{array}{c}\text { Treatment } \\
\text { df }=4\end{array}$ & $\begin{array}{c}\text { Site } \\
\mathrm{df}=1\end{array}$ \\
\hline $\begin{array}{l}\text { Hormosira banksii } \\
\text { canopy cover }\end{array}$ & $\begin{array}{c}\mathrm{MS}_{\mathrm{R}}=179.473 \\
p=0.011\end{array}$ & $\begin{array}{c}\mathrm{MS}_{\mathrm{R}}=588.142 \\
p=0.0001 *\end{array}$ & n.s & n.s & n.s & $\begin{array}{c}\mathrm{MS}_{\mathrm{R}}=76,844.5 \\
p=0.0001\end{array}$ & n.s \\
\hline Species Richness & n.s & $\begin{array}{c}\mathrm{MS}_{\mathrm{R}}=12.151 \\
p=0.0001^{*}\end{array}$ & n.s & $\begin{array}{c}\mathrm{MS}_{\mathrm{R}}=63.880 \\
p=0.0001^{*}\end{array}$ & n.s & n.s & n.s \\
\hline \multicolumn{8}{|c|}{ UNDERSTOREY COVER } \\
\hline $\begin{array}{l}\text { Xenostrobus pulex \& } \\
\text { Capriola implexa }\end{array}$ & n.s & n.s & n.s & n.s & n.s & $\begin{array}{c}\mathrm{MS}_{\mathrm{R}}=30,174.2 \\
p=0.0001\end{array}$ & n.s \\
\hline Bare Rock & $\begin{array}{c}\mathrm{MS}_{\mathrm{R}}=1563.12 \\
p=0.002 *\end{array}$ & $\begin{array}{c}\mathrm{MS}_{\mathrm{R}}=2127.67 \\
p=0.0001^{*}\end{array}$ & n.s & $\begin{array}{c}\mathrm{MS}_{\mathrm{R}}=7219.06 \\
p=0.0001 *\end{array}$ & n.s & n.s & $\begin{aligned} \mathrm{MS}_{\mathrm{R}} & =12,059.0 \\
p & =0.009\end{aligned}$ \\
\hline Sand & $\begin{array}{c}\mathrm{MS}_{\mathrm{R}}=1275.09 \\
p=0.037^{*}\end{array}$ & $\begin{array}{c}\mathrm{MS}_{\mathrm{R}}=2983.68 \\
p=0.0001^{*}\end{array}$ & n.s & $\begin{array}{c}\mathrm{MS}_{\mathrm{R}}=10,801.3 \\
p=0.0001^{*}\end{array}$ & n.s & $\begin{array}{c}\mathrm{MS}_{\mathrm{R}}=10,821.3 \\
p=0.0001\end{array}$ & n.s \\
\hline \multicolumn{8}{|c|}{ MOBILE INVERTEBRATES } \\
\hline Lunella undulatat & $\begin{array}{c}\mathrm{MS}_{\mathrm{R}}=0.611 \\
p=0.0001 *\end{array}$ & $\begin{array}{c}\mathrm{MS}_{\mathrm{R}}=0.445 \\
p=0.003^{*}\end{array}$ & $\begin{array}{c}\mathrm{MS}_{\mathrm{R}}=0.657 \\
p=0.009 *\end{array}$ & n.s & $\begin{array}{c}\mathrm{MS}_{\mathrm{R}}=4.386 \\
p=0.001\end{array}$ & $\begin{array}{c}\mathrm{MS}_{\mathrm{R}}=8.106 \\
p=0.001\end{array}$ & $\begin{array}{c}\mathrm{MS}_{\mathrm{R}}=2.948 \\
p=0.001\end{array}$ \\
\hline Chlorodiloma adelaidae & n.s & n.s & n.s & n.s & $\begin{array}{c}\mathrm{MS}_{\mathrm{R}}=5.445 \\
p=0.002\end{array}$ & $\begin{array}{c}\mathrm{MS}_{\mathrm{R}}=15.755 \\
p=0.0001\end{array}$ & n.s \\
\hline Dicathais orbitat & n.s & $\begin{array}{c}\mathrm{MS}_{\mathrm{R}}=0.596 \\
p=0.004^{*}\end{array}$ & n.s & n.s & n.s & $\begin{array}{c}\mathrm{MS}_{\mathrm{R}}=3.880 \\
p=0.0001\end{array}$ & $\begin{array}{c}\mathrm{MS}_{\mathrm{R}}=1.348 \\
p=0.035\end{array}$ \\
\hline Bembicium nanumt & n.s & $\begin{array}{c}\mathrm{MS}_{\mathrm{R}}=0.866 \\
p=0.004^{*}\end{array}$ & n.s & n.s & n.s & $\begin{array}{c}\mathrm{MS}_{\mathrm{R}}=8.752 \\
p=0.0001\end{array}$ & n.s \\
\hline \multicolumn{8}{|c|}{ PHYSICAL } \\
\hline Temperature & $\begin{array}{c}\mathrm{MS}_{\mathrm{R}}=9.834 \\
p=0.0001 *\end{array}$ & $\begin{array}{c}\mathrm{MS}_{\mathrm{R}}=11.296 \\
p=0.0001 *\end{array}$ & $\begin{array}{c}\mathrm{MS}_{\mathrm{R}}=589.470 \\
p=0.0001^{*}\end{array}$ & $\begin{array}{c}\mathrm{MS}_{\mathrm{R}}=87.398 \\
p=0.0001^{*}\end{array}$ & $\begin{aligned} \mathrm{MS}_{\mathrm{R}} & =27.602 \\
p & =0.021\end{aligned}$ & $\begin{array}{c}\mathrm{MS}_{\mathrm{R}}=156.467 \\
p=0.0001\end{array}$ & $\begin{aligned} \mathrm{MS}_{\mathrm{R}} & =112.350 \\
p & =0.001\end{aligned}$ \\
\hline Light intensity & n.s & n.s & $\begin{array}{c}\mathrm{MS}_{\mathrm{R}}=5111.26 \\
p=0.0001^{*}\end{array}$ & $\begin{array}{c}\mathrm{MS}_{\mathrm{R}}=9461.34 \\
p=0.0001^{*}\end{array}$ & n.s & $\begin{array}{c}\mathrm{MS}_{\mathrm{R}}=40,416.1 \\
p=0.0001\end{array}$ & $\begin{array}{c}\mathrm{MS}_{\mathrm{R}}=10,353.6 \\
\quad p=0.0001\end{array}$ \\
\hline \multicolumn{8}{|c|}{ COVARIATES } \\
\hline Frond length & n.s & $\begin{array}{c}\mathrm{MS}_{\mathrm{R}}=6.528 \\
p=0.015^{*}\end{array}$ & n.s & $\begin{array}{c}\mathrm{MS}_{\mathrm{R}}=22.376 \\
p=0.0001^{*}\end{array}$ & n.s & $\begin{array}{c}\mathrm{MS}_{\mathrm{R}}=1371.70 p= \\
0.0001\end{array}$ & $\begin{array}{c}\mathrm{MS}_{\mathrm{R}}=31.113 \\
p=0.037\end{array}$ \\
\hline Sand depth & $\begin{array}{c}\mathrm{MS}_{\mathrm{R}}=0.512 \\
p=0.02 *\end{array}$ & n.s & n.s & $\begin{array}{c}\mathrm{MS}_{\mathrm{R}}=1.377 \\
p=0.004^{*}\end{array}$ & $\begin{array}{c}\mathrm{MS}_{\mathrm{R}}=1.149 \\
p=0.016\end{array}$ & $\begin{array}{c}\mathrm{MS}_{\mathrm{R}}=1.653 \\
p=0.002\end{array}$ & n.s \\
\hline
\end{tabular}




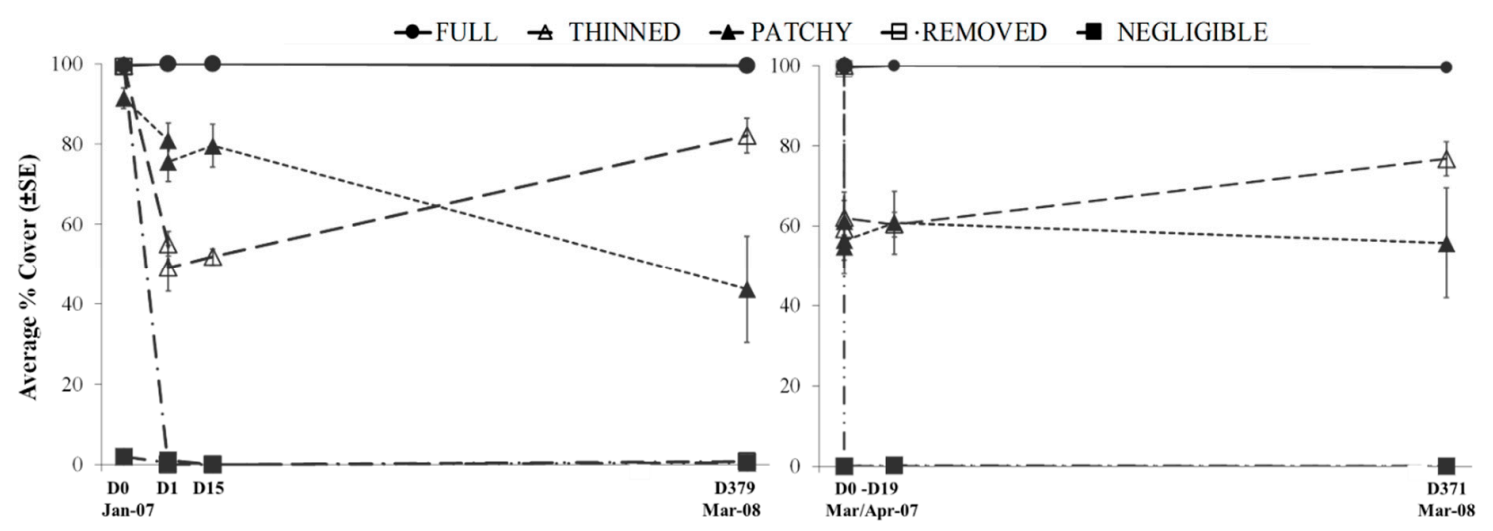

Figure 4. Average \pm SE percentage cover of Hormosira banksii canopy over time and between treatments at 13th Beach (left) and Bridgewater Bay (right). $\mathrm{N}=5$ for all treatments.

One day after canopy manipulations, the understorey cover assemblages were significantly different from each other for all pairwise treatment comparisons except for naturally full, patchy and experimentally thinned treatments at 13th Beach, and the plots with the experimentally removed Hormosira canopy at Bridgewater Bay did not significantly differ from either the patchy or thinned plots (Table 2a, Figure A2). By the end of the experiment at 13th Beach (day 379), significant differences in understorey assemblages amongst all treatments except naturally full, patchy and experimentally thinned treatments remained (Table 2a, Figure A2). At the second experimental site (Bridgewater Bay) however, by the end of the experiment (day 371), the understorey cover assemblages in plots with naturally full canopy differed significantly from all treatments except the experimentally thinned canopy, which had converged on the full treatment by day 5 of the experiment (Table 2, Figure A2). At this site (Bridgewater Bay), the understorey cover assemblages in the patchy treatment differed significantly from only the full treatment by day 371 , but the treatments largely devoid of Hormosira cover (negligible natural cover and experimentally removed) had significantly different understorey cover components to all other treatments (Table 1, Figure A2). Overall the understorey components that contributed most to the separation of treatment groups (as identified by SIMPER, Table A2) at the end of the experiment were the cover of the turfing C. implexa and small mussel X. pulex (individually and in association with each other as an intertwined complex), the amount of sand covering the substratum and bare rock devoid of visible biota (Figure 5).

The abundance of turfing alga Capreolia implexa and small mussel Xenostrobus pulex (combined in the analysis due to common occurrence as an intertwined complex) showed a consistent pattern throughout the experiment (Table 1, Figure 5). Both species were consistently most abundant in the negligible plots (75\% at 13th Beach and $\sim 55 \%$ at Bridgewater Bay, Table 1, Figure 5 at $\sim 20 \%$ cover in patchy plots and either absent or $<3 \%$ cover in all other treatments at both sites (Table 1, Figure 5). Sand cover varied between treatments and sites throughout time, with higher abundance found in full plots when differences occurred (Table 1, Figure 5). Sand depth did not correspond with cover and on many occasions, deeper sand was recorded in plots with a lower overall cover of sand (Table 1 and Figure A4). Deeper sand (0.8-0.4 cm 13th Beach, 1-0.3 cm Bridgewater Bay) was most frequently recorded in full and patchy treatments (Table 1 and Figure A4). Bare rock cover varied through time, between treatments and sites (Table 1, Figure 5). Removed treatments had the most consistent cover of bare rock throughout the experiment ( $\sim 30 \%$ 13th Beach, $\sim 60 \%$ Bridgewater Bay). 
Table 2. Pairwise comparisons of (a) understorey cover and (b) mobile invertebrate assemblages between Hormosira-canopy treatment groups by sites following Permutational multivariate analysis of variance (PERMANOVA) on the significant treatment $\times$ site interaction terms. $P(M C)$ is the $P$-value based on Monte Carlo random draws provides a more robust significance value with the reduced number of possible permutations in pairwise tests; statistical significance $(\alpha=0.05)$ is indicated in bold.

\begin{tabular}{|c|c|c|c|c|c|c|c|c|}
\hline \multicolumn{9}{|c|}{ a. Understorey Cover } \\
\hline 13th Beach & \multicolumn{2}{|c|}{ Day 1} & \multicolumn{2}{|c|}{ Day 5} & \multicolumn{2}{|c|}{ Day 15} & \multicolumn{2}{|c|}{ Day 379} \\
\hline Groups & $t$ & $P(M C)$ & $t$ & $P(M C)$ & $t$ & $P(M C)$ & $t$ & $P(M C)$ \\
\hline Negligible, Full & 2.7355 & 0.005 & 3.1076 & 0.001 & 3.4761 & 0.003 & 3.0716 & 0.002 \\
\hline Negligible, Patchy & 2.261 & 0.011 & 2.0689 & 0.016 & 2.556 & 0.007 & 1.6355 & 0.048 \\
\hline Negligible, Removed & 3.7294 & 0.001 & 4.1516 & 0.002 & 3.8215 & 0.002 & 4.1695 & 0.001 \\
\hline Negligible, Thinned & 2.999 & 0.002 & 2.3286 & 0.004 & 2.7993 & 0.005 & 2.7044 & 0.002 \\
\hline Full, Patchy & 1.32 & 0.175 & 1.7143 & 0.061 & 1.5254 & 0.099 & 1.4554 & 0.112 \\
\hline Full, Removed & 1.7988 & 0.037 & 2.4151 & 0.007 & 2.684 & 0.005 & 5.3762 & 0.001 \\
\hline Full, Thinned & 1.4372 & 0.124 & 1.2142 & 0.23 & 1.4212 & 0.144 & 1.3216 & 0.178 \\
\hline Patchy, Removed & 2.2744 & 0.01 & 1.954 & 0.026 & 1.974 & 0.017 & 2.3982 & 0.007 \\
\hline Patchy, Thinned & 1.5898 & 0.094 & 0.28847 & 0.956 & 1.4853 & 0.108 & 1.0035 & 0.4 \\
\hline Removed, Thinned & 2.1327 & 0.02 & 1.6114 & 0.082 & 2.0228 & 0.035 & 3.4919 & 0.001 \\
\hline Bridgewater Bay & \multicolumn{2}{|c|}{ Day 1} & \multicolumn{2}{|c|}{ Day 5} & \multicolumn{2}{|c|}{ Day 19} & \multicolumn{2}{|c|}{ Day 371} \\
\hline Groups & $t$ & $P(M C)$ & $t$ & $P(M C)$ & $t$ & $P(M C)$ & $t$ & $P(M C)$ \\
\hline Negligible, Full & 3.9928 & 0.001 & 3.472 & 0.003 & 4.3075 & 0.001 & 3.3129 & 0.003 \\
\hline Negligible, Patchy & 2.2683 & 0.01 & 1.791 & 0.055 & 2.9745 & 0.007 & 0.99608 & 0.416 \\
\hline Negligible, Removed & 2.6292 & 0.002 & 2.8406 & 0.005 & 5.0578 & 0.002 & 1.8123 & 0.029 \\
\hline Negligible, Thinned & 3.6341 & 0.003 & 3.4366 & 0.003 & 3.5378 & 0.001 & 2.0145 & 0.017 \\
\hline Full, Patchy & 3.0028 & 0.004 & 1.9309 & 0.043 & 1.9964 & 0.031 & 2.4889 & 0.009 \\
\hline Full, Removed & 3.1564 & 0.002 & 2.5595 & 0.007 & 2.0738 & 0.04 & 2.8531 & 0.005 \\
\hline Full, Thinned & 4.3495 & 0.001 & 1.3148 & 0.199 & 1.857 & 0.08 & 1.0017 & 0.399 \\
\hline Patchy, Removed & 1.4045 & 0.14 & 1.5003 & 0.111 & 1.7736 & 0.053 & 1.3559 & 0.127 \\
\hline Patchy, Thinned & 2.3606 & 0.013 & 1.2967 & 0.187 & 1.7255 & 0.072 & 1.3792 & 0.15 \\
\hline Removed, Thinned & 1.0678 & 0.347 & 1.5106 & 0.099 & 0.47141 & 0.848 & 1.7502 & 0.033 \\
\hline \multicolumn{9}{|c|}{ b. Mobile Invertebrates } \\
\hline 13th Beach & \multicolumn{2}{|c|}{ Day 1} & \multicolumn{2}{|c|}{ Day 5} & \multicolumn{2}{|c|}{ Day 15} & \multicolumn{2}{|c|}{ Day 379} \\
\hline Groups & $t$ & $P(M C)$ & $t$ & $P(M C)$ & $t$ & $P(M C)$ & $t$ & $P(M C)$ \\
\hline Negligible, Full & 2.1068 & 0.004 & 2.4702 & 0.002 & 2.35 & 0.003 & 2.7648 & 0.004 \\
\hline Negligible, Patchy & 2.3273 & 0.003 & 2.3418 & 0.005 & 2.7097 & 0.001 & 2.5555 & 0.001 \\
\hline Negligible, Removed & 3.0379 & 0.002 & 6.046 & 0.001 & 3.7486 & 0.001 & 2.8849 & 0.002 \\
\hline Negligible, Thinned & 3.6249 & 0.001 & 2.7132 & 0.003 & 2.4678 & 0.005 & 2.7919 & 0.005 \\
\hline Full, Patchy & 1.1599 & 0.263 & 1.3268 & 0.128 & 0.80682 & 0.659 & 0.87774 & 0.495 \\
\hline Full, Removed & 1.993 & 0.015 & 3.0928 & 0.003 & 1.9719 & 0.008 & 2.0366 & 0.015 \\
\hline Full, Thinned & 1.982 & 0.016 & 1.6499 & 0.058 & 0.60027 & 0.817 & 0.95089 & 0.452 \\
\hline Patchy, Removed & 2.0558 & 0.02 & 3.2691 & 0.002 & 2.005 & 0.041 & 1.7523 & 0.04 \\
\hline Patchy, Thinned & 1.3835 & 0.141 & 1.8072 & 0.03 & 1.0276 & 0.407 & 1.1334 & 0.315 \\
\hline Removed, Thinned & 3.0643 & 0.006 & 1.512 & 0.154 & 1.6727 & 0.074 & 1.6586 & 0.076 \\
\hline Bridgewater Bay & \multicolumn{2}{|c|}{ Day 1} & \multicolumn{2}{|c|}{ Day 5} & \multicolumn{2}{|c|}{ Day 19} & \multicolumn{2}{|c|}{ Day 371} \\
\hline Groups & $t$ & $P(M C)$ & $t$ & $P(M C)$ & $t$ & $P(M C)$ & $t$ & $P(M C)$ \\
\hline Negligible, Full & 3.8373 & 0.002 & 3.3296 & 0.002 & 2.8513 & 0.002 & 2.8735 & 0.001 \\
\hline Negligible, Patchy & 1.7435 & 0.028 & 2.0275 & 0.016 & 1.5883 & 0.052 & 0.84361 & 0.554 \\
\hline Negligible, Removed & 2.2146 & 0.02 & 2.2748 & 0.01 & 1.8333 & 0.028 & 1.0569 & 0.366 \\
\hline Negligible, Thinned & 2.2084 & 0.003 & 2.1693 & 0.005 & 1.3721 & 0.111 & 1.7979 & 0.02 \\
\hline Full, Patchy & 2.5234 & 0.003 & 1.9401 & 0.021 & 2.0477 & 0.013 & 1.9566 & 0.016 \\
\hline Full, Removed & 2.4472 & 0.006 & 2.3379 & 0.003 & 2.291 & 0.019 & 1.9659 & 0.017 \\
\hline Full, Thinned & 1.436 & 0.111 & 1.6196 & 0.069 & 1.8522 & 0.015 & 1.3402 & 0.174 \\
\hline Patchy, Removed & 1.8608 & 0.026 & 1.5259 & 0.107 & 1.7104 & 0.03 & 0.92669 & 0.524 \\
\hline Patchy, Thinned & 1.3634 & 0.132 & 1.4108 & 0.123 & 1.1969 & 0.231 & 0.98985 & 0.419 \\
\hline Removed, Thinned & 1.5459 & 0.048 & 1.2201 & 0.226 & 1.1947 & 0.24 & 1.2061 & 0.209 \\
\hline
\end{tabular}



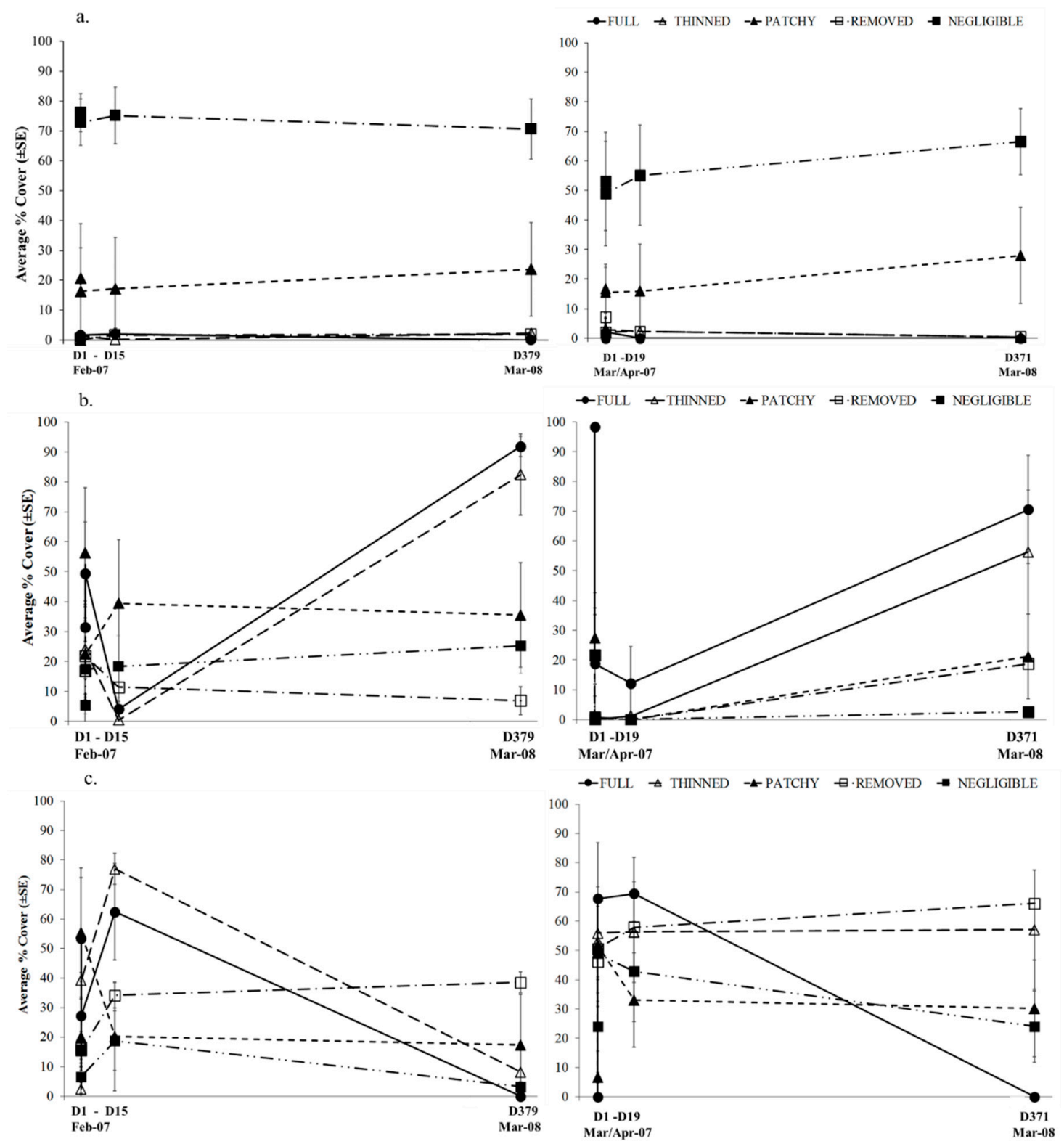

Figure 5. Average \pm SE percentage cover of (a) C. implexa and X. pulex, (b) sand (c) bare rock for each treatment over time since manipulation of the canopy. 13th Beach on left hand side of panel, Bridgewater Bay on right hand side. $\mathrm{N}=5$ for all treatments.

For the mobile invertebrate assemblages associated with the different levels of Hormosira-canopy cover, there were significant differences in assemblages amongst all treatments one day after manipulation, except patchy vs. both full and thinned at 13th Beach and thinned vs. both patchy and full at Bridgewater Bay (Table 2, Figure 6). However by the end of the experiment, whilst there were no significant differences in the mobile invertebrate assemblages associated with full, patchy and thinned treatments at 13th Beach, full and patchy treatments were significantly different with respect to mobile invertebrates at Bridgewater Bay (Table 2, Figure 6). Mobile invertebrate assemblages associated with the naturally negligible Hormosira canopy and experimentally removed canopy were significantly different from most other canopy treatments over the duration of the experiment for both sites Table 2, Figure 6 and was principally driven (SIMPER, Table A3) by the abundance of the turbinid Lunella undulata, the trochid Chlorodiloma adelaidae and predatory whelk Dicathais orbita in treatments with a full or intermediate Hormosira canopy present; and juvenile littorinids, B. nanum and abundant limpets, in treatments lacking a Hormosira canopy (Figure 6, juvenile littorinids and limpets not shown). 

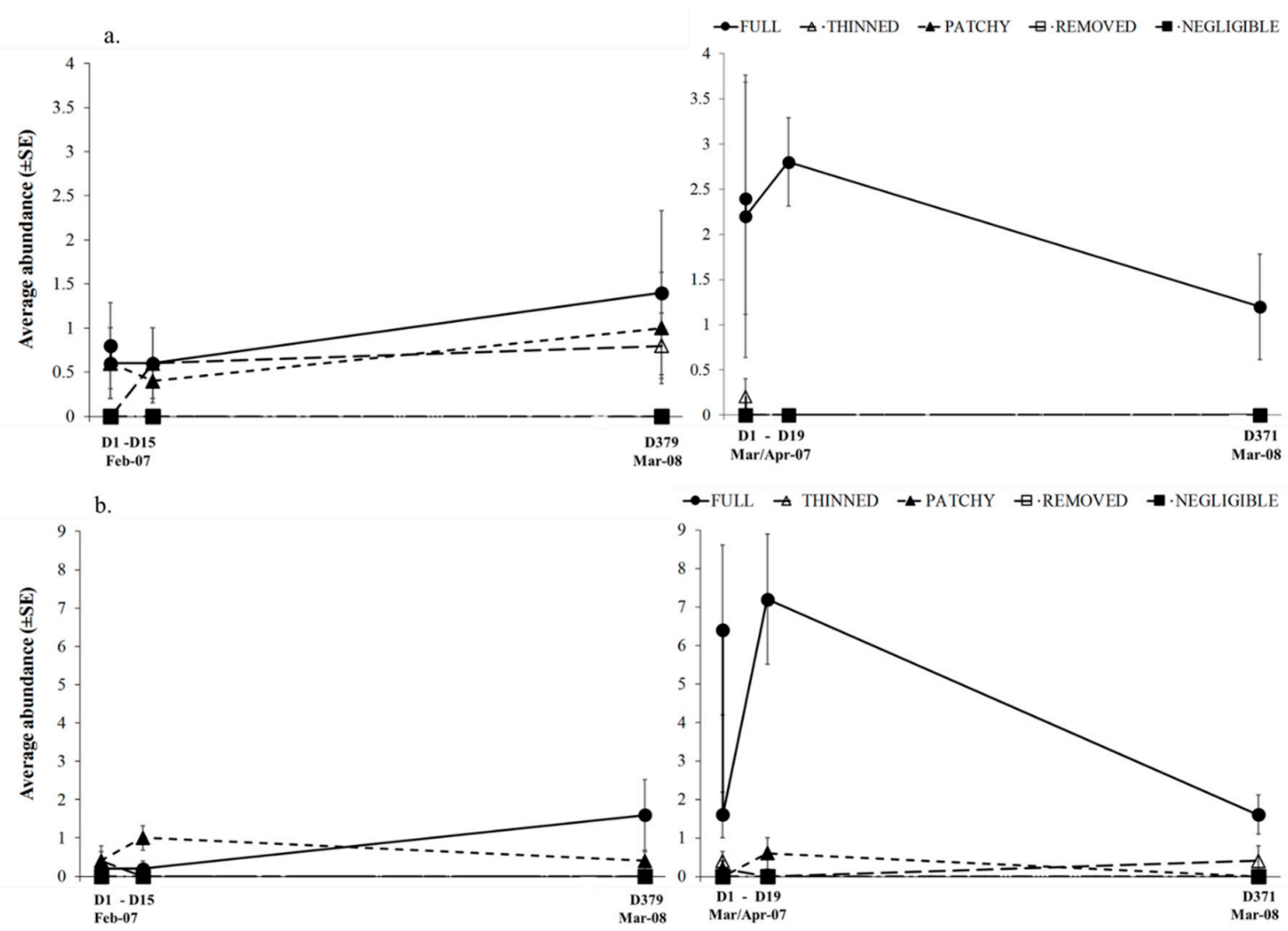

$\rightarrow$-FULL $\rightarrow$ THINNED - -PATCHY $\bullet \cdot$ REMOVED $\rightarrow$ NEGLIGIBLE
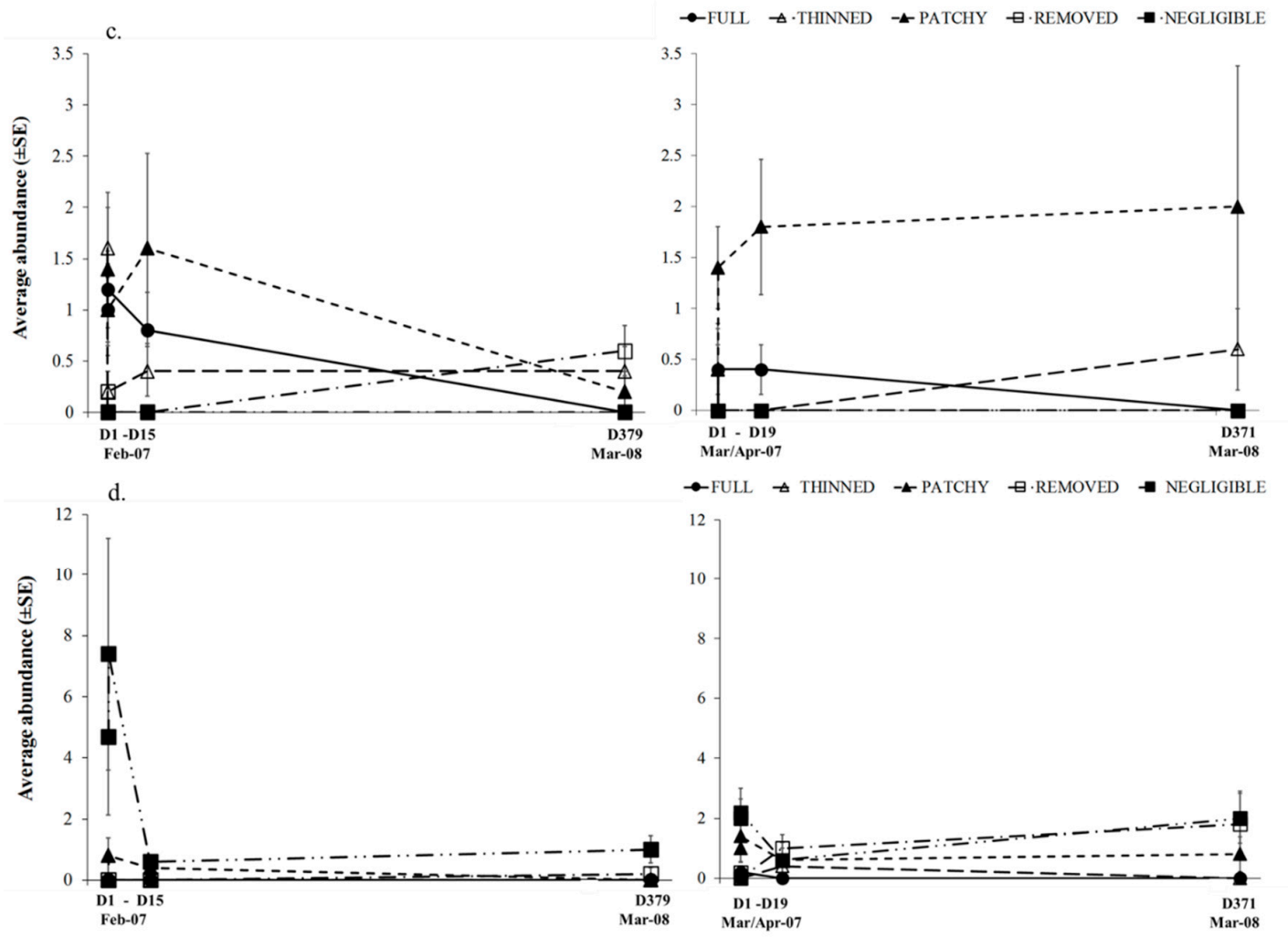

Figure 6. Mean \pm SE percentage cover of (a) Lunella undulata (b) Chlorodiloma adelaidae, (c) Dicathais orbita (d) Bembicium nanum, for each treatment over time since manipulation of the canopy. 13th Beach on left hand site of the panel, Bridgewater Bay on right hand side. $\mathrm{N}=5$ for all treatments.

The turbinid Lunella undulata was consistently most abundant in the full canopy plots at both sites through time (Table 1, Figure 6), with approximately double the average abundance at Bridgewater Bay compared with 13th Beach. Lunella undulata was found in patchy and thinned canopy plots at 
Bridgewater Bay but not at 13th Beach (Table 1, Figure 6). None were recorded in negligible or removed canopy treatments at either site (Table 1, Figure 6). The trochid Chlorodiloma adelaidae, was most abundant in the full canopy plots at both sites through time, though more were found in patchy and thinned treatments at 13th Beach during day 15 sampling (Table 1, Figure 6). The predatory whelk Dicathais orbita varied in abundance between treatments and time, though was most often more abundant in patchy, full and thinned canopy treatments and in higher overall abundance at 13th Beach (Table 1, Figure 6). The grazing gastropod Bembicium nanum varied in abundance between treatments through time at both sites, mostly in highest abundance in negligible canopy treatment plots (Table 1, Figure 6).

Species richness ranged from an average of 4.5-9 at 13th Beach and 4.5-10.5 at Bridgewater Bay, differing between treatments and sites through time with no consistent pattern (Table 1, Figure 7). The temperature remained lower under full canopies (average $20^{\circ} \mathrm{C}$ ) compared with all other treatments on all but one occasion at one site (day 5, Bridgewater Bay) during the experiment (Table 1, Figure 8). Negligible and/or removed canopy treatments had the highest temperatures (average $24^{\circ} \mathrm{C}$ ) with patchy and thinned canopy plots having intermediate temperatures (average $22^{\circ} \mathrm{C}$ and $21^{\circ} \mathrm{C}$ respectively, Table 1, Figure 8). Light intensity was consistently lower in full canopies compared with all other treatments throughout the experiment (Table 1, Figure 9). Negligible canopy plots usually had the highest relative levels of light, though this wasn't always statistically significant and is likely influenced by intermittent cloud cover during sampling (Table 1, Figure 9). Light levels in patchy and thinned treatments were generally intermediate between the two extremes of canopy cover (Table 1, Figure 9). Hormosira banskii frond length was found to be longer in full canopy plots at both sites (average 14 $\mathrm{cm}$ 13th Beach, $11 \mathrm{~cm}$ at Bridgewater Bay, Table 1, Figure A5). Frond length averaged $9 \mathrm{~cm}$ in patchy and thinned plots at 13th beach; 10 and $7 \mathrm{~cm}$ at Bridgewater Bay, respectively (Table 1, Figure A5). The fronds found in negligible and removed canopy plots never exceeded $2 \mathrm{~cm}$ throughout the course of the experiment (Figure A5).

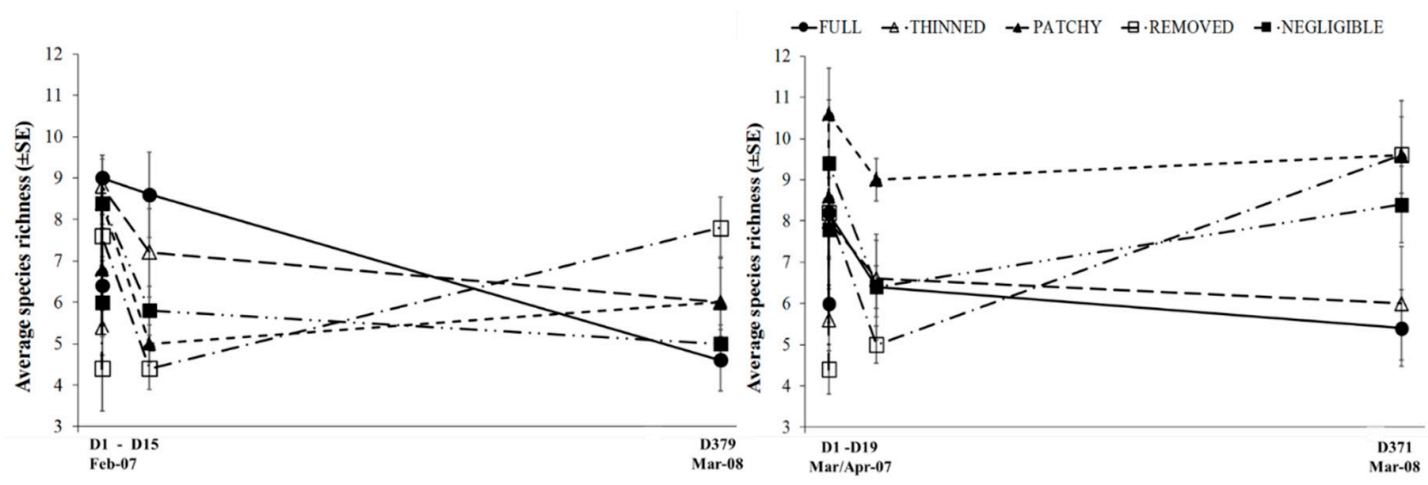

Figure 7. Average species richness \pm se between treatments and over time at 13th Beach (left hand side) and Bridgewater Bay (right hand side).
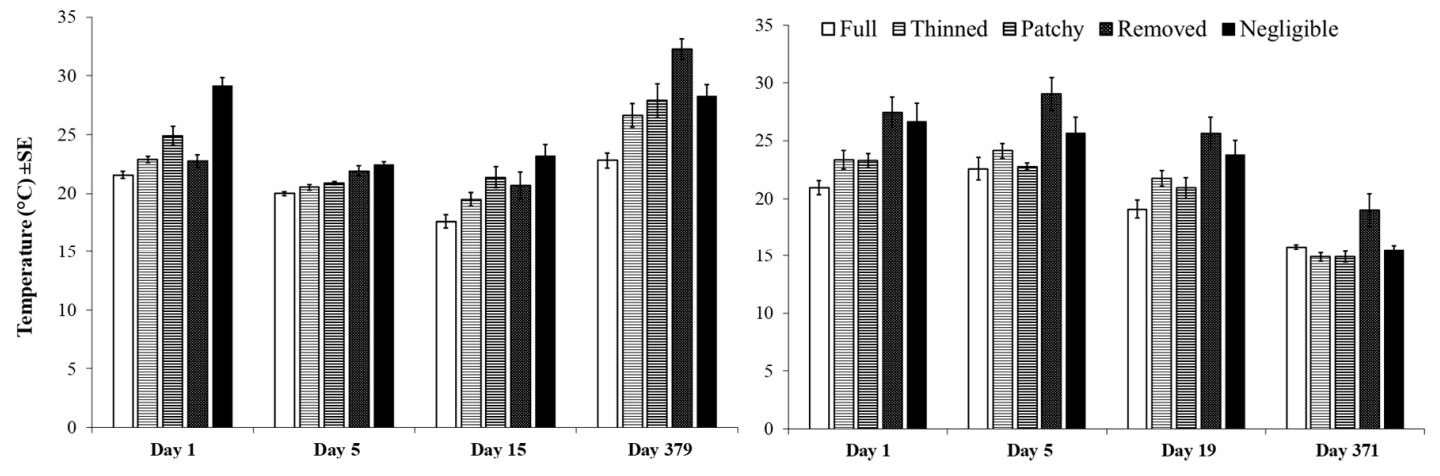

Figure 8. Average temperature $\left({ }^{\circ} \mathrm{C}\right) \pm$ se between treatments and over time at 13 th Beach (left hand side) and Bridgewater Bay (right hand side). 

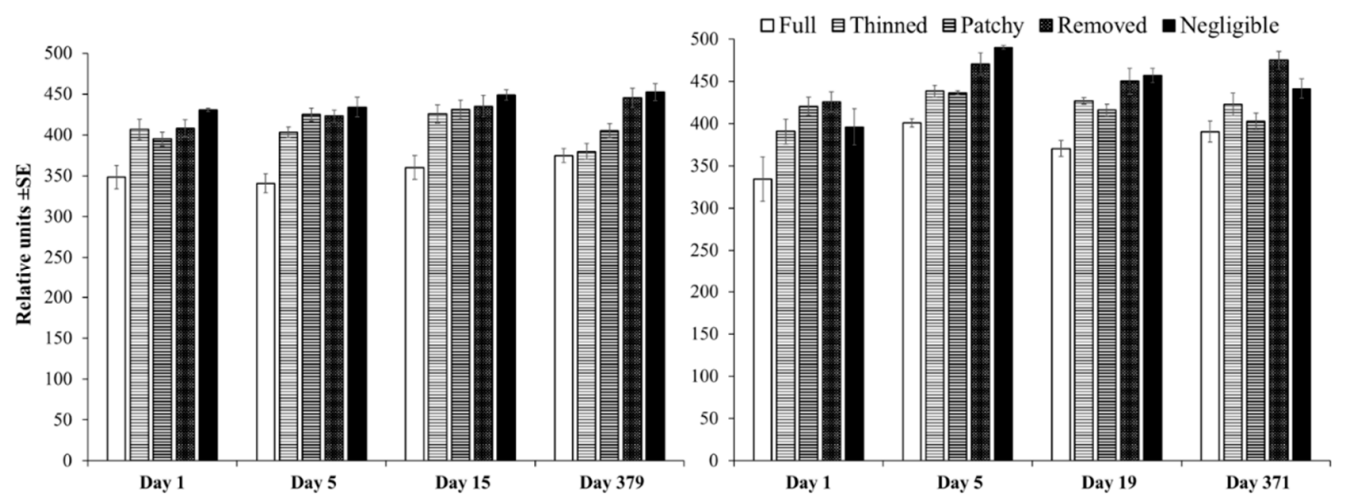

Figure 9. Average light intensity \pm se as relative units between treatments and over time at 13th Beach (left hand side) and Bridgewater Bay (right hand side).

\section{Discussion}

\subsection{Hormosira banksii as An Ecosystem Engineer}

The results of this study support the suggestion of Keough and Quinn [5] that 'established' H. banksii canopies function as ecosystem engineers on Victorian rocky shores by providing environmentally buffered refuges (cool and shaded) for particular species (see also References $[2,9,12,21,27])$. We found differences in assemblages associated with different natural states of the canopy (full, patchy, negligible cover) across four sites; and like other studies $[2,5,9,12,21]$ a loss of species occurred with the removal and part-removal of full canopies at two sites. Canopies that were naturally patchy did not function in the same way as full canopies, the environmental parameters measured under these canopies and the associated species assemblages were generally intermediate between those found under full canopies and in the absence of a canopy. This study builds on the findings of studies undertaken in Victoria and New Zealand $[2,5,9,12,17,21]$ by examining the role of $H$. banksii canopies not only in response to disturbance but also on areas of the shore that have naturally patchy canopies. This demonstrates that the assemblages associated with patchy canopies result from the reduced canopy cover and not disturbance per se.

The understorey and macroinvertebrate assemblages in areas of naturally negligible canopy cover (which were between or adjacent to canopy habitats with no differences in rock type, exposure or height on shore should) differed to those where the canopy was removed. Naturally, negligible cover areas on the shore were dominated by grazing snails including limpets and periwinkles, and often aggregations of the mussel Xenostrobus pulex and the turfing alga Capreolia implexa. Since the disturbance treatments did not have assemblages that matched the natural controls (negligible areas) it suggests that it takes longer than 1 year for an alternative community such as the Xenostrobus pulex and Capreolia implexa complex to establish. This is consistent with studies showing variable recruitment (e.g., [37]).

The physical conditions and associated assemblages within thinned canopy treatments and patchy canopies varied throughout time and between sites with negligible and full canopy areas varying from discrete to similar (consistent with studies in South Australia [26] and in New Zealand [12]). As found in New Zealand [9] no replacement of $H$. banksii occurred in this study. In contrast to similar studies in the northern hemisphere (e.g., [7]), no other dominant canopy forming perennial algae extend into the intertidal region of Victorian rocky shores. In contrast to Lilley and Schiel [9], other fucoids were rarely recorded in the understorey of $H$. banksii and were generally only observed in very low areas of the shore, rarely exposed by tides (e.g., Cystophora torulosa). This may be due to differences in $H$. banskii frond length (up to $18 \mathrm{~cm}$ in our study, up to 25 in Lilley and Schiel [9], see also Reference [38]) or climatic differences in extreme temperatures during tidal emersion between Victorian and southern New Zealand shores. The results of this study demonstrate that dense and patchy canopies support different species assemblages and have differing effects on the physical environment. Thus although 
H. banksii dominates reef platforms, the magnitude of its ecosystem engineer function for associated communities is influenced by the amount of canopy cover.

\subsection{Species Associations with Cover}

This study found that particular species were found to be associated with full canopies, patchy canopies and areas where canopies were absent from the shore. Some of these species were the same as those found in other studies such as Lunella undulata (as Turbo undulatus) in full canopies [21], and Bembicium nanum in patchy canopies [24]. Lunella undulata was generally only found within canopies or in submerged areas of the rock platform during low tide throughout the study, which suggests that they are positively associated with the buffered conditions supplied by a full canopy. Interestingly species richness did not vary consistently between treatments during the experiment despite the differences observed in species assemblages between treatments. This demonstrates the power of recording species-specific data and using multivariate analysis when investigating autogenic ecosystem engineers [10]. Our results differed from a Victorian study examining trampling disturbance and its effect on H. banksii assemblages [21]. King's study found background variation in the abundance of L. undulata and Chlorodiloma odontis (as Austrocochlea odontis) was stronger than the trampling intensity [21]. In our study, L. undulata and C. adelaidae consistently differed in abundance between treatments indicating disturbance and canopy cover investigations are not equal. Although $H$. banksii canopies studied by Underwood [24] correspond to the 'patchy' areas in this study (similar frond length and cover), he found no difference in the abundance of the grazing gastropod B. nanum between canopy and non-canopy treatments. In our study, they were most abundant in negligible areas on all except one sampling day suggesting either site-specific/latitudinal effects or that this species has different habitat preferences in the absence of disturbance.

Despite the lack of coralline turf, the fleshy turf-forming alga Capreolia implexa was common in both patchy (all sites) and negligible-cover plots (at both experimental sites) and was observed to form large mats discrete from $H$. banksii often in conjunction with the mussel Xenostrobus pulex. Hormosira banksii was rarely observed growing within the $C$. implexa turf suggesting this species may be competitively excluding $\mathrm{H}$. banksii from growing on some areas of the shore (as found for coralline turf elsewhere, [39]), though this would need to be tested experimentally.

\subsection{Alternate Habitat Types and Stable States}

What was evident during this study was that discrete habitats are occurring on Victorian rocky shores, made up of stable, full-canopy H. banksii beds, areas of patchy (possibly disturbed) areas of canopy mixed with a range of other habitats, and 'bare' (negligible canopy) areas that consist of rock with abundant grazers, and substrate dominated by aggregating mussels, or turfing algae. Despite such habitats commonly referred to in the literature as vertical 'zones', the results of this study support the earlier refutation of vertical zonation on temperate Australian shores by Underwood [40], as all these discrete habitats occurred without variation in exposure, height on shore or other observable abiotic factors. The multiple habitats occurring on the shores investigated in this study and their different species assemblages support the concept of multiple stable states (though planned manipulative experiments are necessary to test this [41]). The differences in assemblages associated with patchy or dense H. banksii cover demonstrates that it functions as an autogenic ecosystem engineer at least at the covers investigated. Since removed and negligible-cover plots supported alternative assemblages, it is evident that not all species on the shore are dependent on canopy cover as habitat, and its possible species such as turfing algae and aggregating mussels could also be functioning as ecosystem engineers (singularly or providing cumulative effects e.g., Reference [42]), although not at the same scale as the canopy alga e.g., mussels sampled during this study were $\leq 1 \mathrm{~cm}$ in height. It was clear that the presence of these multiple habitats across a shore allows a higher overall shore biodiversity than would exist with only one or few habitats, even extensive and dense $H$. banksii. Since predictable assemblages 
were associated with easily identifiable habitat areas, rapid assessment of reef health could be possible if applied to areas of high conservation value.

\subsection{The Influence of Sand}

One aspect of the study that added a level of complexity to the ecosystem engineering function of $H$. banksii, in comparison to the literature on intertidal canopy algal assemblages, was the abundance of sand accumulated under $H$. banksii canopy. King [21] found that sand accumulated into H. banksii mats during winter and spring and suggested it could be a cause of natural disturbance decreasing H. banksii cover. Airoldi and Hawkins [43] found that sediment accumulation on rocky shores in the United Kingdom reduced the grazing and even survival of the limpet Patella vulgata (commonly associated with algal canopies). Given the findings of Airoldi and Hawkins [43], the accumulation of sediment under H. banksii canopies in this study may explain the lack of limpets found in the understorey in contrast to studies in the northern hemisphere. Sand accumulation may have also led to the underestimation of some understorey species such as encrusting coralline algae. Encrusting coralline algae wasn't found to differ in abundance between treatments but was recorded in the removed treatments at both sites in the short term following disturbance before being, lost presumably due to high light and/or temperature exposure. In many of the full canopies during this study sand was a major component of the understorey with depths often 3-4 $\mathrm{mm}$ at both experimental sites, precluding identification of encrusting and very small species buried by the sand. In terms of negative effects on $H$. banksii, sand may cause loss of $H$. banksii cover due to the smothering of lower vesicles (observed at several sites) making it susceptible to breakage [44], sand has been shown to also prevent the attachment of $H$. banksii recruits [45]. It is possible high sand accumulation in H. banksii canopies may be contributing to the comparatively lower abundances of understorey algae and invertebrates recorded in observations of other canopies such as Ascophyllum nodosum in the northern hemisphere where sand cover was not found in significant amounts (see [46]). Further well-planned investigations into the role of sand on intertidal rocky reefs [47] may well provide valuable insight into this finding.

\section{Conclusions}

Full canopies (within the vertical range of $H$. banksii) provided habitat for species that are not found elsewhere on the reef at four sites. Low canopy cover (both natural and disturbed) resulted in different species than found within an intact canopy, correlating with a reduction in the ability of the canopy to buffer temperature and light stress. Patchy canopies (between $40 \%-60 \%$ cover) have species assemblages and physical conditions intermediate between full canopies and areas where H. banksii was absent on the shore.

Previous studies into canopy-forming H. banksii on intertidal rocky shores have highlighted the problem of background variation preventing clarity in their conclusions $[9,10,12,21]$. By examining the background variation in support of the response of the associated assemblage to disturbed areas of $H$. banksii, this study clearly demonstrates that $H$. banksii canopies function as autogenic ecosystem engineers on Victorian rocky intertidal shores, increasing diversity at the shore scale. Despite overall similar outcomes to that found in other studies of H. banksia $[2,9,12,21,25]$, the species assemblages found here did differ from those reported elsewhere supporting the suggestion by Lilley and Schiel [9] that "superficially similar communities in different geographic regions may have different ecological mechanisms affecting structure". These results suggest that site-specific evaluation and monitoring of intertidal communities are required to adequately detect the stability and health of rocky shores in relation to canopy algae. Our results demonstrate that to maintain high biodiversity at the seascape level on these shores, a combination of dense and patchy H. banksii canopy in addition to areas devoid of $H$. banksii canopy is ideal.

Author Contributions: Conceptualization, J.B.P., A.B.; Methodology, J.B.P.; Software, J.B.P., T.D.O. and A.B.; Validation, J.B.P., A.B., M.J.K., T.D.O.; Formal Analysis, J.B.P. and A.B.; Investigation, J.B.P.; Resources, T.D.O., M.J.K. and A.B.; Data Curation, J.B.P. and A.B.; Writing-Original Draft Preparation, J.B.P.; Writing-Review and 
Editing, J.B.P., A.B., T.D.O., M.J.K.; Visualization, J.B.P.; Supervision, A.B., T.D.O.; M.J.K.; Project Administration, J.B.P. and T.D.O.; Funding Acquisition, T.D.O.

Funding: This research was funded by an Australian National Heritage Trust grant awarded to T.D.O, project no: 202244. JBP was funded by a studentship under this grant and a Melbourne University Graduate Research scholarship.

Acknowledgments: Acknowledgement is given to Rebecca Citroen, Sera Cutler, Trudy Costa, Robert Pocklington and John Pocklington for field assistance. Gerry Kraft assisted with the identification of algae. The Marine Research Group (The Field Naturalists Club of Victoria) assisted with invertebrate identification. Dane Balodis created the map of study sites. Trudy Costa, Prue Addison, and Liz Greaves provided discussion and feedback throughout the study. Drafts of this manuscript were improved by feedback from Jorge Gutierrez and two anonymous reviewers. Research in National Parks was carried out under permits (10003820 \& 10003879) pursuant to the National Parks Act 1975, research at other sites was carried out under permit (RP699) pursuant to the Fisheries Act 1995.

Conflicts of Interest: The authors declare no conflict of interest.

\section{Appendix A}

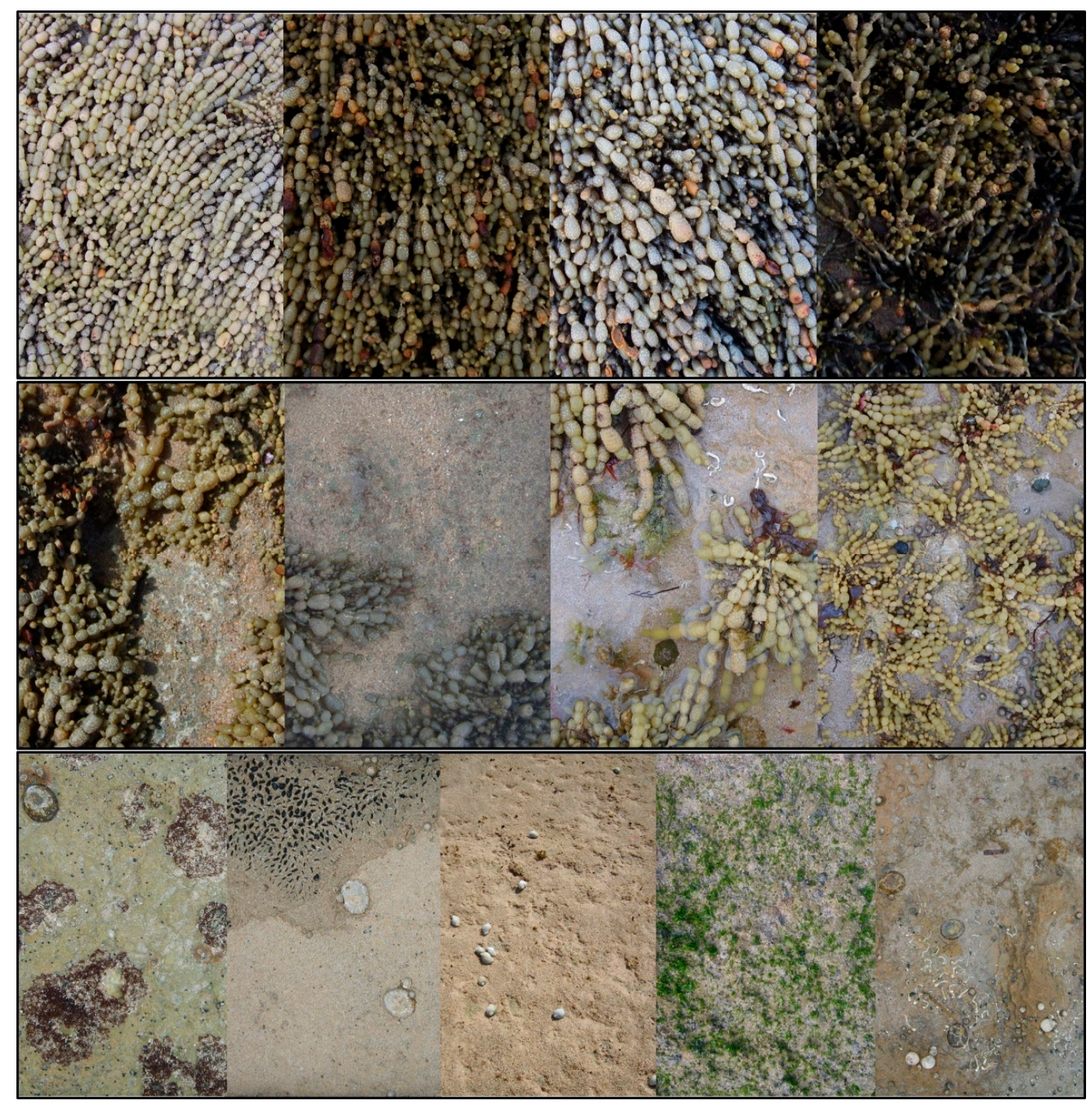

Figure A1. Photo pane showing dense (top), patchy (middle) and absent/negligible (bottom) areas occurring on rocky seashores in Victoria and as sampled. The scale of each image is approximately $20 \mathrm{~cm}$ across. 
Table A1. Species and component list by site and type (> 78 species)

\begin{tabular}{|c|c|c|c|c|}
\hline & Bridgewater Bay & 13th Beach & Sorrento Back Beach & Point Roadknight \\
\hline Primary Algae & $\begin{array}{c}\text { Capreolia implexa } \\
\text { Cladophora sp. } \\
\text { Coralline Turf } \\
\text { Hormosira banksii } \\
\text { Scytosiphon lomentaria } \\
\text { Ulva sp. }\end{array}$ & $\begin{array}{l}\text { Capreolia implexa } \\
\text { Ceramium sp. } \\
\text { Cladophora sp. } \\
\text { Colpomenia sinuosa } \\
\text { Coralline Turf } \\
\text { Encrusting Coralline } \\
\text { Hormosira banksii } \\
\text { Sargassum sp. } \\
\text { Laurencia filiformis } \\
\text { Laurencia spp. } \\
\text { Ulva sp. } \\
\text { Unidentified Reds }\end{array}$ & $\begin{array}{l}\text { Capreolia implexa } \\
\text { Cladophora sp. } \\
\text { Coralline Turf } \\
\text { Hormosira banksii } \\
\text { Laurencia sp. } \\
\text { Rivularia sp. } \\
\text { Ulva sp. }\end{array}$ & $\begin{array}{c}\text { Capreolia implexa } \\
\text { Coralline turf } \\
\text { Diplocladia patersonis } \\
\text { Encrusting Coralline } \\
\text { Hormosira banksii } \\
\text { Notheia anomala } \\
\text { Scytosiphon lomentaria } \\
\text { Ulva sp. }\end{array}$ \\
\hline $\begin{array}{c}\text { Understorey Algae } \\
\text { 'Coralline Turf' is likely } \\
\text { Corallina officinalis but due to } \\
\text { compact form was not able to be } \\
\text { positively identified in the field. }\end{array}$ & $\begin{array}{l}\text { Caulocystis cephalornithos } \\
\text { Ceramium sp. } \\
\text { Chaetomorpha sp. } \\
\text { Cladophora sp. } \\
\text { Colpomenia sinuosa } \\
\text { Coralline Turf } \\
\text { Diplocladia patersonis } \\
\text { Encrusting Coralline } \\
\text { Gelidium australe } \\
\text { Laurencia botryoides } \\
\text { Laurencia filiformis } \\
\text { Laurencia spp. } \\
\text { Notheia anomala } \\
\text { Scytosiphon lomentaria } \\
\text { Sargassum sp. } \\
\text { Ulva sp. } \\
\text { Unidentified Encrusting Black } \\
\text { Unidentified Epiphytes } \\
\text { Unidentified Reds }\end{array}$ & $\begin{array}{l}\text { Encrusting green } \\
\text { Capreolia implexa } \\
\text { Caulerpa brownii } \\
\text { Ceramium sp. } \\
\text { Chaetomorpha sp. } \\
\text { Cladophora sp. } \\
\text { Colpomenia sinuosa } \\
\text { Coralline Encrusting } \\
\text { Coralline Turf } \\
\text { Cystophora spp. } \\
\text { Laurencia botryoides } \\
\text { Laurencia filiformis } \\
\text { Laurencia spp. } \\
\text { Notheia anomala } \\
\text { Pachydictyon sp. } \\
\text { Sargassum sp. } \\
\text { Ulva sp. } \\
\text { Unidentified Reds }\end{array}$ & $\begin{array}{l}\text { Capreolia implexa } \\
\text { Ceramium sp. } \\
\text { Cladophora sp. } \\
\text { Cystophora sp. } \\
\text { Coralline Turf } \\
\text { Diplocladia patersonis } \\
\text { Encrusting Coralline } \\
\text { Laurencia sp. } \\
\text { Rivularia sp. } \\
\text { Ulva sp. }\end{array}$ & $\begin{array}{c}\text { Capreolia implexa } \\
\text { Ceramium sp. } \\
\text { Cladophora sp. } \\
\text { Coralline Turf } \\
\text { Diplocladia patersonis } \\
\text { Encrusting Coralline } \\
\text { Laurencia sp. } \\
\text { Rivularia sp. } \\
\text { Splachnidium rugosum } \\
\text { Unidentified Reds }\end{array}$ \\
\hline
\end{tabular}


Table A1. Cont.

\begin{tabular}{|c|c|c|c|c|}
\hline & Bridgewater Bay & 13th Beach & Sorrento Back Beach & Point Roadknight \\
\hline \multicolumn{5}{|l|}{ Invertebrates } \\
\hline Bivalves & $\begin{array}{l}\text { Brachidontes rostratus } \\
\text { Xenostrobus pulex } \\
\text { Unidentified Bivalve }\end{array}$ & $\begin{array}{l}\text { Xenostrobus pulex } \\
\text { Unidentified Bivalve }\end{array}$ & Xenostrobus pulex & Xenostrobus pulex \\
\hline Polycheates & Galeolaria caespitosa & Galeolaria caespitosa & Galeolaria caespitosa & Galeolaria caespitosa \\
\hline $\begin{array}{l}\text { Limpets } \\
\text { (and false limpets) }\end{array}$ & $\begin{array}{l}\text { Cellana tramoserica } \\
\text { Lottia mixta } \\
\text { Montfortula rugosa } \\
\text { Notoacmea alta } \\
\text { Notoacmea flammea } \\
\text { Onchidella nigricans } \\
\text { Patelloida alticostata } \\
\text { Patelloida latistrigata } \\
\text { Siphonaria diemenensis } \\
\text { Siphonaira zelandica } \\
\text { Juvenile limpets } \\
\text { (unidentified) }\end{array}$ & $\begin{array}{l}\text { Cellana tramoserica } \\
\text { Lottia mixta } \\
\text { Notoacmea flammea } \\
\text { Notoacmea sp. } \\
\text { Onchidella nigricans } \\
\text { Patelloida alticostata } \\
\text { Siphonaria diemenensis } \\
\text { Siphonaria zelandica } \\
\text { Juvenile limpets } \\
\text { (unidentified) }\end{array}$ & $\begin{array}{l}\text { Cellana tramoserica } \\
\text { Lottia mixta } \\
\text { Notoacmea alta } \\
\text { Notoacmea flammea } \\
\text { Notoacmea petterdi } \\
\text { Notoacmea sp. } \\
\text { Patelloida alticostata } \\
\text { Patelloida latistrigata } \\
\text { Siphonaria diemenensis } \\
\text { Siphonaria funiculata } \\
\text { Siphonaria zelandica } \\
\text { Juvenile limpets } \\
\text { (unidentified) }\end{array}$ & $\begin{array}{l}\text { Cellana tramoserica } \\
\text { Montfortula rugosa } \\
\text { Notoacmea sp. } \\
\text { Notoacmea flammea } \\
\text { Notoacmea petterdi } \\
\text { Patella peroni } \\
\text { Patelloida alticostata } \\
\text { Patelloida latistrigata } \\
\text { Siphonaria diemenensis } \\
\text { Siphonaria zelandica } \\
\text { Siphonaria funiculata } \\
\text { Juvenile limpets } \\
\text { (unidentified) }\end{array}$ \\
\hline Gastropods & $\begin{array}{c}\text { Austrocochlea constricta } \\
\text { Austrocochlea porcata } \\
\text { Austrolittornia unifasciata } \\
\text { Bembicium nanum } \\
\text { Cantharidius pulcherimus } \\
\text { Chlorodiloma adelaidea } \\
\text { Chlorodiloma odontis } \\
\text { Cominella lineolata } \\
\text { Dicathais orbita } \\
\text { Littorinid juvenile } \\
\text { (unidentified) } \\
\text { Mitre sp. } \\
\text { Phasianotrochus eximus } \\
\text { Thalotia conica } \\
\text { Lunella undulata }\end{array}$ & $\begin{array}{c}\text { Austrocochlea constricta } \\
\text { Bembicium nanum } \\
\text { Cantharidius pulcherimus } \\
\text { Chlorodiloma adelaidea } \\
\text { Chlorodiloma odontis } \\
\text { Cominella lineolata } \\
\text { Cystophora sp. } \\
\text { Dentrimitrella pulla } \\
\text { Dicathais orbita } \\
\text { Lepsellia vinosa } \\
\text { Littorinid juvenile } \\
\text { (unidentified) } \\
\text { Mitre cabonaria } \\
\text { Phasianotrochus eximus } \\
\text { Thalotia conica } \\
\text { Lunella undulata } \\
\text { Waimatea obscura }\end{array}$ & $\begin{array}{c}\text { Austrocochlea constricta } \\
\text { Austrolittorina unifasciata } \\
\text { Bembicium nanum } \\
\text { Chlorodiloma adelaidae } \\
\text { Cominella lineolata } \\
\text { Dicathais orbita } \\
\text { Littorinid juvenile } \\
\text { (unidentified) } \\
\text { Nerita atramentosa } \\
\text { Lunella undulata }\end{array}$ & $\begin{array}{c}\text { Austrocochlea constricta } \\
\text { Austrocochlea juvenile } \\
\text { Bembicium nanum } \\
\text { Chlorodiloma adelaidae } \\
\text { Cominella lineolata } \\
\text { Dicathis orbita } \\
\text { Lepsiella vinosa } \\
\text { Littorinid juvenile } \\
\text { (unidentified) } \\
\text { Mitre sp. } \\
\text { Nerita atramentosa } \\
\text { Lunella undulata }\end{array}$ \\
\hline
\end{tabular}


Table A1. Cont.

\begin{tabular}{|c|c|c|c|c|}
\hline & Bridgewater Bay & 13th Beach & Sorrento Back Beach & Point Roadknight \\
\hline Echinoderms & $\begin{array}{l}\text { Meridiastra calcar } \\
\text { Parvulastra exigua }\end{array}$ & & Meridiastra calcar & $\begin{array}{l}\text { Meridiastra calcar } \\
\text { Parvulastra exigua }\end{array}$ \\
\hline Crustaceans & $\begin{array}{c}\text { Chthalaumus antennatus } \\
\text { Paragrapsus quadradentatus } \\
\text { Guinusia chabrus } \\
\text { Naxia aurita } \\
\text { Unidentified Amphipods } \\
\text { Unidentified Copepods } \\
\text { Unidentified Harpactocoids } \\
\text { Unidentified Isopods }\end{array}$ & $\begin{array}{l}\text { Chthalaumus antennatus } \\
\text { Naxia aurita } \\
\text { Nectocarcinus turbculosa } \\
\text { Paragrapsus quadradentatus } \\
\text { Guinusia chabrus } \\
\text { Unidentified Amphipods } \\
\text { Unidentified Copepods } \\
\text { Unidentified Harpactocoids } \\
\text { Unidentified Isopods }\end{array}$ & $\begin{array}{c}\text { Cthalaumus antennatus } \\
\text { Paragrapsus quadradentatus } \\
\text { Paragrapsus sp. } \\
\text { Unidentified Isopods } \\
\text { Unidentified Amphipods }\end{array}$ & $\begin{array}{l}\text { Chthalaumus antennatus } \\
\text { Paragrapsus quadradentatus } \\
\text { Unidentified Isopods }\end{array}$ \\
\hline Anemones & $\begin{array}{l}\text { Actinia tenebrosa } \\
\text { Anthothoe albocinta } \\
\text { Aulactinia verartra } \\
\text { Oulactis mucosa } \\
\text { Oulactis sp. } \\
\text { Unidentified anemones }\end{array}$ & $\begin{array}{l}\text { Anthothoe albocinta } \\
\text { Oulactis mucosa } \\
\text { Oulactis sp. }\end{array}$ & $\begin{array}{l}\text { Oulactis mucosa } \\
\text { Oulactis sp. } \\
\text { Unidentified Anemone }\end{array}$ & $\begin{array}{l}\text { Actinia tenebrosa } \\
\text { Aulactinia verartra }\end{array}$ \\
\hline Chitons & Unidentified Chiton & Unidentified Chiton & Unidentified Chiton & \\
\hline
\end{tabular}



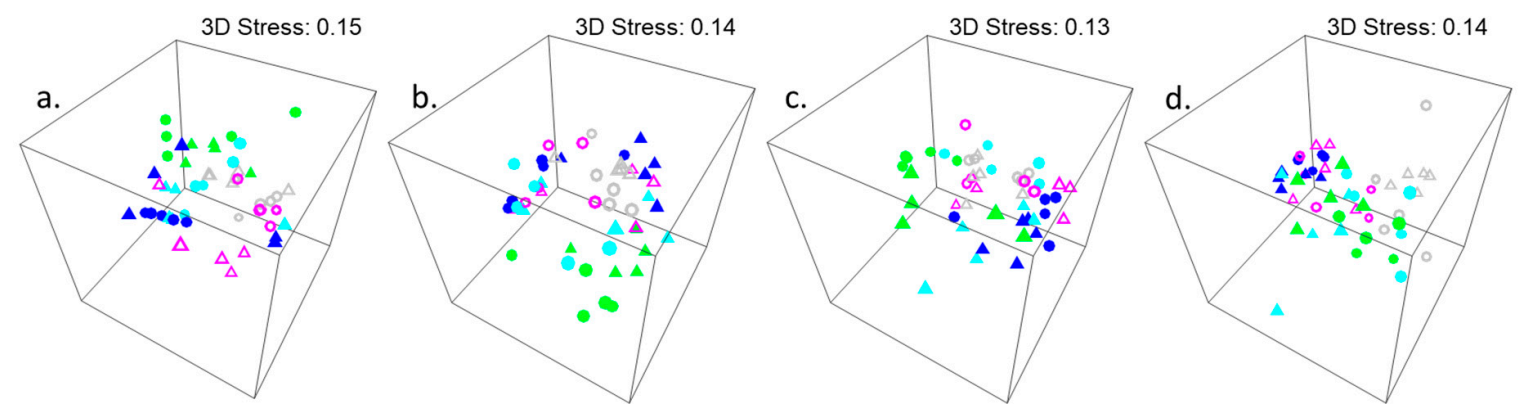

Figure A2. Non-metric multidimensional scaling (nMDS) plots of understorey cover assemblages associated with different levels (full cover $=$ dark blue, patchy cover $=$ aqua, negligible cover $=$ green, thinned $=$ pink, removed $=$ grey) of Hormosira cover (a) 1 day, (b) 5 days, (c) 15/19 days and (d) 371/379 days following manipulation at each of two sites (13th Beach $=$ triangles, Bridgewater Bay $=$ circles). All data were fourth-root transformed. 3D nMDS plots based on Bray-Curtis dissimilarities are shown where stress exceeded 0.20 for $2 \mathrm{D}$ plots.
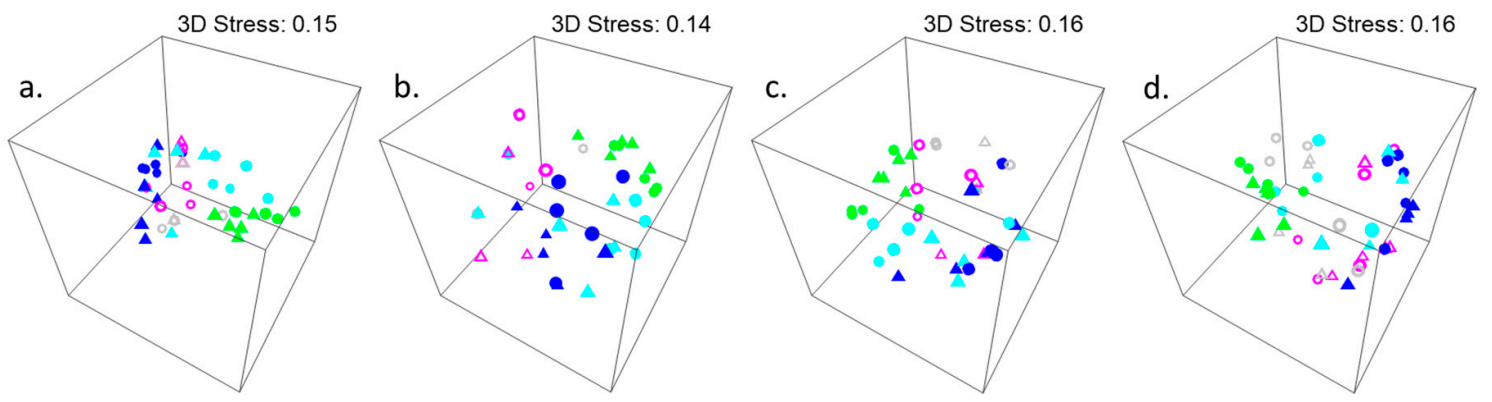

Figure A3. Non-metric multidimensional scaling (nMDS) plots of mobile invertebrate assemblages associated with different levels (full cover $=$ dark blue, patchy cover $=$ aqua, negligible cover $=$ green, thinned $=$ pink, removed $=$ grey) of Hormosira cover (a) 1 day, (b) 5 days, (c) 15/19 days and (d) 371/379 days following manipulation at each of two sites (13th Beach $=$ triangles, Bridgewater Bay $=$ circles). All data were fourth-root transformed. 3D nMDS plots based on Bray-Curtis dissimilarities are shown where stress exceeded 0.20 for $2 \mathrm{D}$ plots. 
Table A2. Summary SIMPER table: Average dissimilarity of treatment pairs for understorey cover combining Bridgewater Bay and 13th Beach. Contributions > 10\% given by understorey component/species.

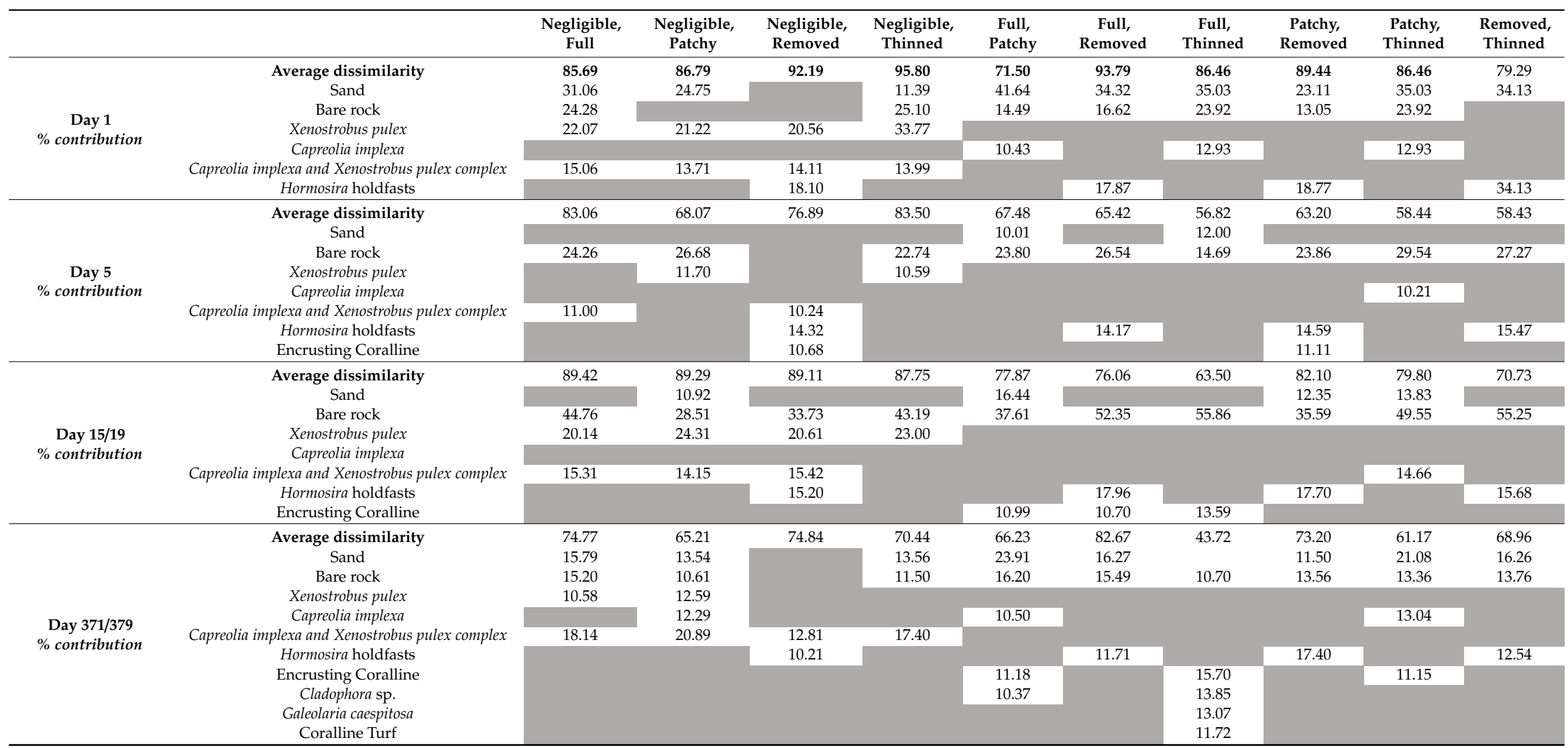


Table A3. Summary SIMPER table: Average dissimilarity of treatment pairs for mobile macroinvertebrates combining Bridgewater Bay and 13th Beach. Contributions $>10 \%$ given by species.

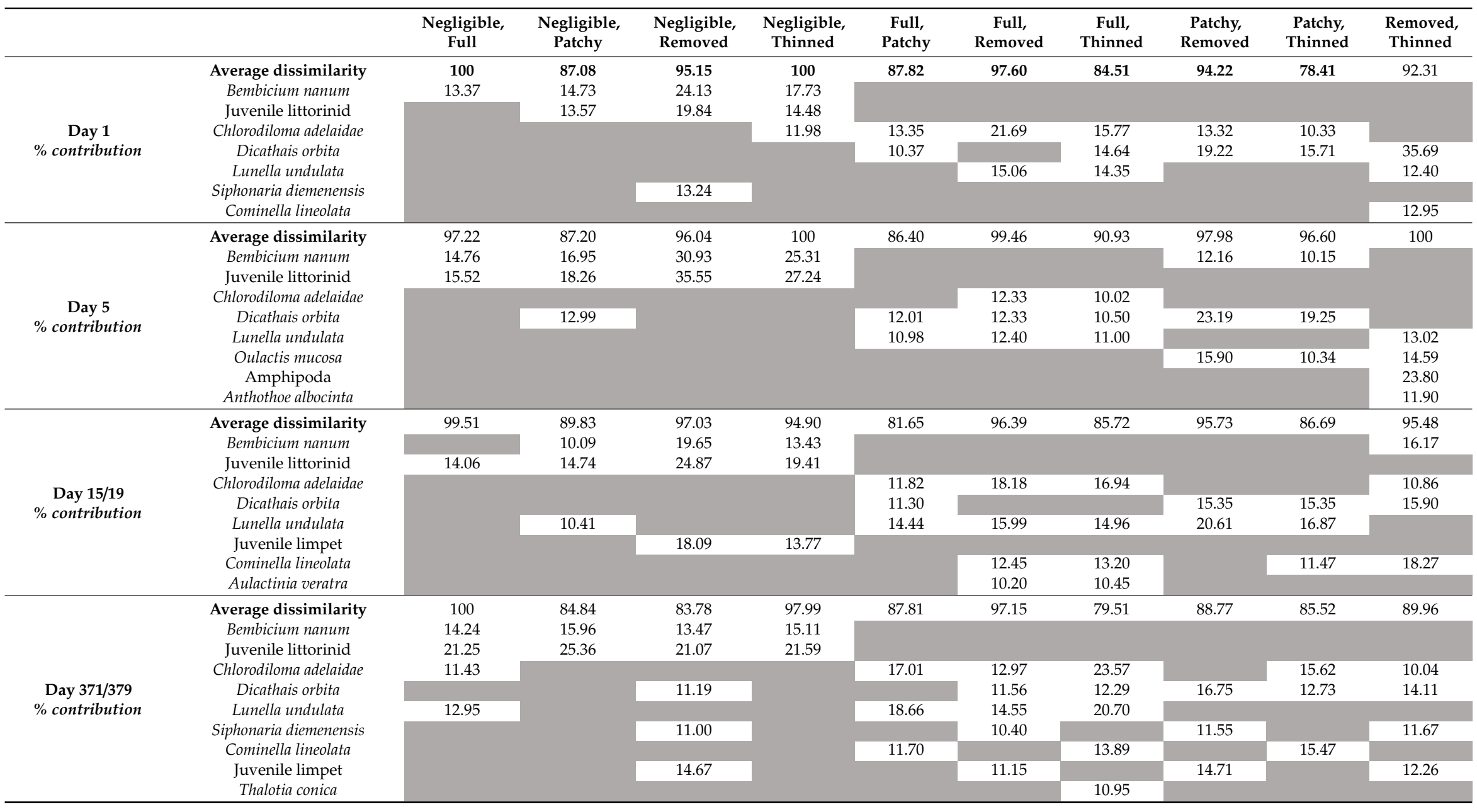




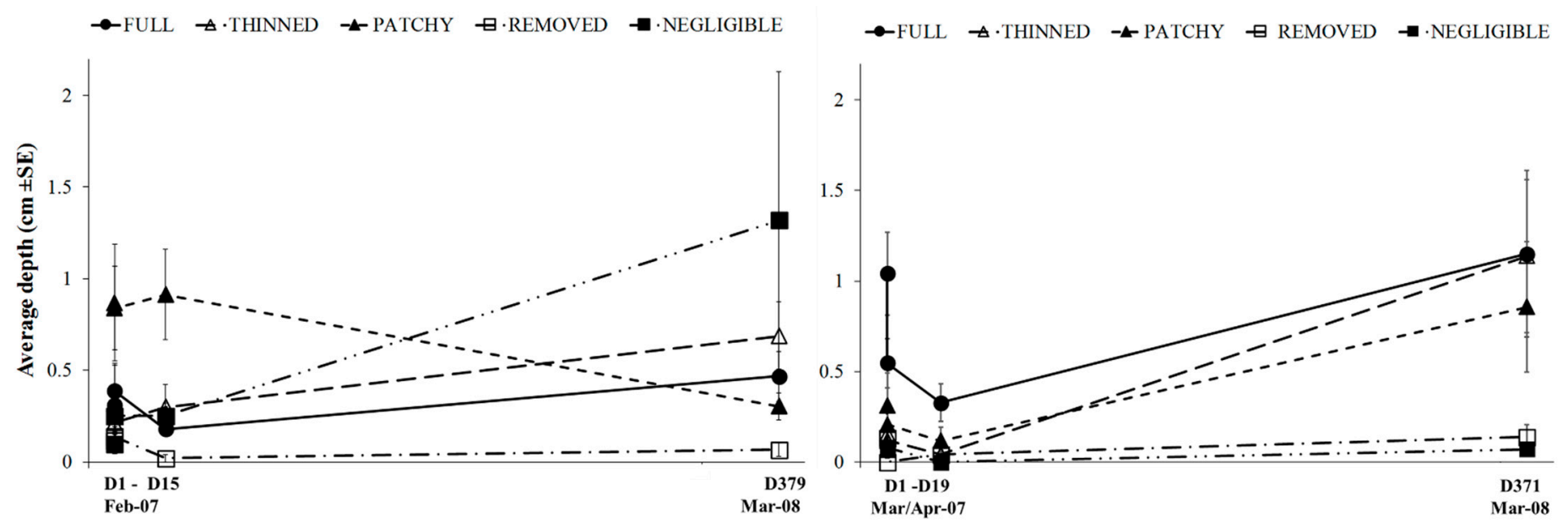

Figure A4. Average sand depth ( $\mathrm{cm} \pm$ se) between treatments and over time at 13th Beach (left hand side) and Bridgewater Bay (right hand side).

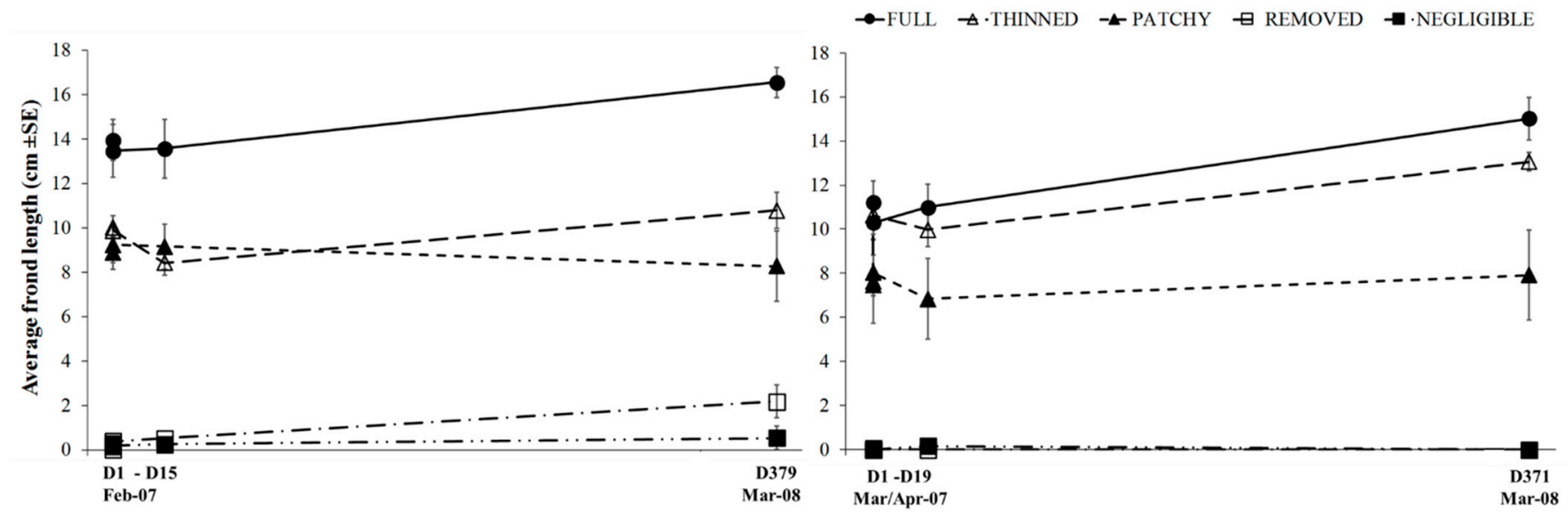

Figure A5. Average Hormosira frond length $(\mathrm{cm} \pm \mathrm{se})$ between treatments and over time at 13th Beach (left hand side) and Bridgewater Bay (right hand side) 


\section{References}

1. Menge, B.A. Predation Intensity in a Rocky Intertidal Community: Effect of an algal canopy, wave action and desiccation on predator feeding rates. Oecologia 1978, 34, 17-35. [CrossRef]

2. Povey, A.; Keough, M.J. Effects of trampling on plant and animal populations on rocky shores. Oikos 1991, 61, 355-368. [CrossRef]

3. Jones, C.G.; Lawton, J.H.; Shachak, M. Organisms as ecosystem engineers. Oikos 1994, 69, 373-386. [CrossRef]

4. Alper, J. Ecosystem 'Engineers' Shape Habitats for Other Species. Science 1998, 280, 1195-1196. [CrossRef]

5. Keough, M.J.; Quinn, G.P. Effects of periodic disturbances from trampling on rocky intertidal algal beds. Ecol. Appl. 1998, 8, 141-161.

6. Schiel, D.R.; Taylor, D.I. Effects of trampling on a rocky intertidal algal assemblage in southern New Zealand. J. Exp. Mar. Biol. Ecol. 1999, 235, 213-235.

7. Jenkins, S.R.; Norton, T.A.; Hawkins, S.J. Long term effects of Ascophyllum nodosum canopy removal on mid shore community structure. J. Mar. Biol. Assoc. UK 2004, 84, 327-329. [CrossRef]

8. Dudgeon, S.; Petraitis, P.S. First year demography of the foundation species, Ascophyllum nodosum, and its community implications. Oikos 2005, 109, 405-415. [CrossRef]

9. Lilley, S.A.; Schiel, D.R. Community effects following the deletion of a habitat-forming alga from rocky marine shores. Oecologia 2006, 148, 672-681. [CrossRef]

10. Schiel, D.R. Rivets or bolts? When single species count in the function of temperate rocky reef communities. J. Exp. Mar. Biol. Ecol. 2006, 338, 233-252. [CrossRef]

11. Hastings, A.; Byers, J.E.; Crooks, J.A.; Cuddington, K.; Jones, C.G.; Lambrinos, J.G.; Talley, T.S.; Wilson, W.G. Ecosystem engineering in space and time. Ecol. Lett. 2007, 10, 153-164. [CrossRef] [PubMed]

12. Schiel, D.; Lilley, S. Gradients of disturbance to an algal canopy and the modification of an intertidal community. Mar. Ecol. Prog. Ser. 2007, 339, 1-11. [CrossRef]

13. Benedetti Cecchi, L.; Cinelli, F. Canopy removal experiments in Cystoseira-dominated rockpools from the Western coast of the Mediterranean (Ligurian Sea). J. Exp. Mar. Biol. Ecol. 1992, 155, 69-83. [CrossRef]

14. Cervin, G.; Åberg, P. Do littorinids affect the survival of Ascophyllum nodosum germlings? J. Exp. Mar. Biol. Ecol. 1997, 218, 35-47. [CrossRef]

15. Pavia, H.; Carr, H.; Åberg, P. Habitat and feeding preferences of crustacean mesoherbivores inhabiting the brown seaweed Ascophyllum nodosum (L.) Le Jol. and its epiphytic macroalgae. J. Exp. Mar. Biol. Ecol. 1999, 236, 15-32. [CrossRef]

16. Coleman, M.A.; Clark, J.S.; Doblin, M.A.; Bishop, M.J.; Kelaher, B.P. Genetic differentiation between estuarine and open coast ecotypes of a dominant ecosystem engineer. Mar. Freshw. Res. 2018. [CrossRef]

17. Wootton, H.F.; Keough, M.J. Disturbance type and intensity combine to affect resilience of an intertidal community. Mar. Ecol. Prog. Ser. 2016, 560, 121-133. [CrossRef]

18. Tait, L.W.; Schiel, D.R. Legacy Effects of Canopy Disturbance on Ecosystem Functioning in Macroalgal Assemblages. PLoS ONE 2011, 6, e26986. [CrossRef] [PubMed]

19. Raffaelli, D. The grazer-algae interaction in the intertidal zone of New Zealand rocky shores. J. Exp. Mar. Biol. Ecol. 1979, 38, 81-100. [CrossRef]

20. Underwood, A.J. The vertical distribution and seasonal abundance of intertidal macroalgae on a rocky shore in New South Wales. J. Exp. Mar. Biol. Ecol. 1984, 78, 199-220. [CrossRef]

21. King, A. Monitoring and Management of Human Activity on Rocky Shores. Ph.D. Thesis, Melbourne University, Melbourne, Australia, 1992.

22. Bellgrove, A. Recruitment of Intertidal Macroalgae on a Wave-Exposed Rocky Coast; Monash Clayton: Melbourne, Australia, 1998.

23. Ralph, P.J.; Morrison, D.A.; Addison, A. A quantitative study of the patterns of morphological variation within Hormosira banksii (Turner) Decaisne (Fucales: Phaeophyta) in south-eastern Australia. J. Exp. Mar. Biol. Ecol. 1998, 225, 285-300. [CrossRef]

24. Underwood, A.J. Grazing and disturbance: An experimental analysis of patchiness in recovery from a severe storm by the intertidal alga Hormosira banksii on rocky shores in New South Wales. J. Exp. Mar. Biol. Ecol. 1998, 231, 291-306. [CrossRef]

25. Underwood, A.J. Physical disturbances and their direct effect on an indirect effect: Responses of an intertidal assemblage to a severe storm. J. Exp. Mar. Biol. Ecol. 1999, 232, 125-140. [CrossRef] 
26. Pocklington, J.B. Positive Interactions on Rocky Seashores. Are They Important, or Can They Be Ignored? Honours Thesis, Flinders University of South Australia, Adelaide, Australia, 2003.

27. Lilley, S.A. Removal of Habitat-Forming Species and the Consequences on Community Biodiversity in New Zealand Rocky Shore Ecosystems. Master's Thesis, Canterbury University, Christchurch, New Zealand, 2004.

28. Macinnis-Ng, C.M.O.; Morrison, D.A.; Ralph, P.J. Temporal and spatial variation in the morphology of the brown macroalga Hormosira banksii (Fucales, Phaeophyta). Bot. Mar. 2005, 48, 198-207. [CrossRef]

29. Addison, P.F.E.; Koss, R.S.; O'Hara, T.D. Recreational use of a rocky intertidal reef in Victoria: Implications for ecological research and management. Aust. J. Environ. Manag. 2008, 15, 169-179. [CrossRef]

30. Schoenwaelder, M.E.A. Physode distribution and the effect of 'Thallus sunburn' in Hormosira banksii (Fucales, Phaeophyceae). Bot. Mar. 2002, 45, 262-266. [CrossRef]

31. Bishop, M.J.; Morgan, T.; Coleman, M.A.; Kelaher, B.P.; Hardstaff, L.K.; Evenden, R.W. Facilitation of molluscan assemblages in mangroves by the fucalean alga Hormosira banksii. Mar. Ecol. Prog. Ser. 2009, 392, 111-122. [CrossRef]

32. Short, A.D. Beaches of the Victorian Coast E Port Phillip Bay: A Guide to Their Nature, Characteristics, Surf and Safety; University of Sydney \& Surf Life Saving Victoria: Sydney, Australia, 2006.

33. Bird, E. The Coast of Victoria: The Shaping of Scenery; Melbourne University Press: Carlton, Australia, 1993.

34. Kruskal, J.B. Non-parametric multidimensional scaling: A numerical method. Psychometrika 1964, 29, 115-129. [CrossRef]

35. Clarke, K.R. Non-parametric multivariate analyses of changes in community structure. Aust. J. Ecol. 1993, 18, 117-143. [CrossRef]

36. Anderson, M.J.; Gorley, R.N.; Clarke, K.R. PERMANOVA+ for PRIMER: Guide to Software and Statistical Methods; Primer-E Limited: Plymouth, UK, 2008.

37. Bellgrove, A.; Clayton, M.N.; Quinn, G.P. An integrated study of the temporal and spatial variation in the supply of propagules, recruitment and assemblages of intertidal macroalgae on a wave-exposed rocky coast, Victoria, Australia. J. Exp. Mar. Biol. Ecol. 2004, 310, 207-225. [CrossRef]

38. Gemelli, F.; Johnson, C.R.; Wright, J.T. Gastropod communities associated with different morphologies of the intertidal seaweed Hormosira banksii. Mar. Freshw. Res. 2019, 70, 280-291. [CrossRef]

39. Bellgrove, A.; McKenzie, P.; McKenzie, J.; Sfiligoj, B. Restoration of the habitat-forming fucoid alga Hormosira banksii at effluent-affected sites: Competitive exclusion by coralline turfs. Mar. Ecol. Prog. Ser. 2010, 419, 47-56. [CrossRef]

40. Underwood, A.J. A refutation of critical tidal levels as determinates of the structure of intertidal communities on British shores. J. Exp. Mar. Biol. Ecol. 1978, 33, 185-202. [CrossRef]

41. Petraitis, P.S.; Latham, R.E. The Importance of Scale in Testing the Origins of Alternative Community States. Ecology 1999, 80, 429-442. [CrossRef]

42. Gutiérrez, J.; Bagur, M.; Palomo, M. Algal Epibionts as Co-Engineers in Mussel Beds: Effects on Abiotic Conditions and Mobile Interstitial Invertebrates. Diversity 2019, 11, 17. [CrossRef]

43. Airoldi, L.; Hawkins, S.J. Negative effects of sediment deposition on grazing activity and survival of the limpet Patella vulgata. Mar. Ecol. Prog. Ser. 2007, 332, 235-240. [CrossRef]

44. McKenzie, P.F.; Bellgrove, A. Dislodgment and attachment strength of the intertidal macroalga Hormosira banksii (Fucales, Phaeophyceae). Phycologia 2009, 48, 335-343. [CrossRef]

45. Schiel, D.R.; Wood, S.A.; Dunmore, R.A.; Taylor, D.I. Sediment on rocky intertidal reefs: Effects on early post-settlement stages of habitat-forming seaweeds. J. Exp. Mar. Biol. Ecol. 2006, 331, 158-172. [CrossRef]

46. Pocklington, J.B.; Jenkins, S.R.; Bellgrove, A.; Keough, M.J.; O’Hara, T.D.; Masterson-Algar, P.E.; Hawkins, S.J. Disturbance alters ecosystem engineering by a canopy-forming alga. J. Mar. Biol. Assoc. UK 2018, 98, 687-698. [CrossRef]

47. Airoldi, L. The effects of sedimentation on rocky coast assemblages. In Oceanography and Marine Biology, An Annual Review; Gibson, R.N., Atkinson, R.J.A., Eds.; Aberdeen University Press/Allen \& Unwin: London, UK, 2003; Volume 41, pp. 161-236.

(C) 2019 by the authors. Licensee MDPI, Basel, Switzerland. This article is an open access article distributed under the terms and conditions of the Creative Commons Attribution (CC BY) license (http://creativecommons.org/licenses/by/4.0/). 